\title{
The Energetic Significance of Cooking
}

\section{Citation}

Carmody, Rachel N. and Richard W. Wrangham. 2009. The energetic significance of cooking. Evolutionary Anthropology 57(4): 379-91.

\section{Published Version}

doi:10.1016/j.jhevol.2009.02.011

\section{Permanent link}

http://nrs.harvard.edu/urn-3:HUL.InstRepos:5283945

\section{Terms of Use}

This article was downloaded from Harvard University's DASH repository, and is made available under the terms and conditions applicable to Open Access Policy Articles, as set forth at http:// nrs.harvard.edu/urn-3:HUL.InstRepos:dash.current.terms-of-use\#OAP

\section{Share Your Story}

The Harvard community has made this article openly available.

Please share how this access benefits you. Submit a story.

\section{Accessibility}


The energetic significance of cooking

\author{
Rachel N. Carmody and Richard W. Wrangham ${ }^{a}$ \\ Department of Anthropology, Harvard University \\ 11 Divinity Avenue, Cambridge, MA 02138
}

${ }^{a}$ Corresponding author

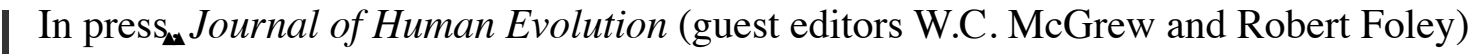

2009

Keywords: energy, cooking, raw, starch, meat, processing, Lower Paleolithic, Homo 


\section{Abstract}

While cooking has long been argued to improve the diet, the nature of the improvement has not been well defined. As a result, the evolutionary significance of cooking has variously been proposed as being substantial or relatively trivial. In this paper, we evaluate the hypothesis that an important and consistent effect of cooking food is a rise in its net energy value. The pathways by which cooking influences net energy value differ for starch, protein and lipid, and we therefore consider plant and animal foods separately. Evidence of compromised physiological performance among individuals on raw diets supports the hypothesis that cooked diets tend to provide energy. Mechanisms contributing to energy being gained from cooking include increased digestibility of starch and protein, reduced costs of digestion for cooked versus raw meat, and reduced energetic costs of detoxification and defense against pathogens. If cooking indeed consistently improves the energetic value of foods through such mechanisms, its evolutionary impact depends partly on the relative energetic benefits of non-thermal processing methods used prior to cooking. We suggest that if non-thermal processing methods, such as pounding, were used by Lower Paleolithic Homo, they likely provided an important increase in energy gain over unprocessed raw diets. However, cooking has critical effects not easily achievable by nonthermal processing, including the relatively complete gelatinization of starch, efficient denaturing of proteins, and killing of foodborne pathogens. This means that however sophisticated the non-thermal processing methods were, cooking would have conferred incremental energetic benefits. While much remains to be discovered, we conclude that the adoption of cooking would have led to an important rise in energy availability. For this reason, we predict that cooking had substantial evolutionary significance. 


\section{Introduction}

With respect to energy the significance of cooking for human evolution has been subject to contrasting interpretations. On the one hand, energetic consequences are often treated as minor. Thus even anthropologists on the forefront of research on fire and diet commonly propose that the primary effect of cooking is to broaden the diet. For example, Alperson-Afil and Goren-Inbar (2006, p. 74) suggested that “... fire enabled protection from predators, warmth and light, and the exploitation of a new range of foods." Gowlett (2006, p. 306) likewise suggested that "fire use became advantageous at an early date, for reasons of adaptation to climate, and extension of diet." Ungar et al. (2006, p. 215) lumped cooking together with digging sticks as examples of material culture that would have "improved access to [underground storage organs] and the nutrients they contain." Such statements imply that if there are any energetic consequences of cooking, they are not sufficiently large to be evolutionarily important.

On the other hand, cooking is sometimes regarded as "a technological way of externalizing part of the digestive process" that "not only reduces toxins in food but also increases its digestibility" (Aiello and Wheeler, 1995, p. 210). Such effects could potentially yield large amounts of energy (Wrangham et al., 1999). A net rise in the energy value of the diet is theoretically important because the total size of the energy budget affects numerous aspects of evolutionary biology, including body mass, rates of growth and reproduction, defense against parasites and pathogens, and investments in locomotion (Leonard and Robertson, 1997; Ellison, 2001; Aiello and Key, 2002). If cooking provides significant amounts of energy, it can therefore be expected to have had major effects on human evolution. 
Accordingly, such questions as whether cooking consistently improves energy acquisition, and if so, how much energy it provides, need to be resolved. Unfortunately, no discipline has paid much attention to these matters. Nutritional scientists have reported numerous energetic effects of cooking. However, many of the effects are in opposite directions, few have been quantified in terms of calories, and there has been virtually no effort to integrate conclusions about the effect of cooking on specific nutrients, or through different mechanisms, into an overall picture of its energetic consequences for different food types. Table 1 illustrates the problem by reviewing diverse claims about the effects of cooking. For instance, with respect to protein, some authors find that processing with heat tends to cause an increase in its digestibility (e.g. Davies et al., 1987), others see the effect as neutral (e.g. Bodwell and Anderson, 1986), while others state that it causes a reduction in digestibility (e.g. Jenkins, 1988). Even specialists on particular food types such as meat, milk or eggs have done little to consider the role of cooking on energy. For example, the effects of cooking on the energy value of meat "do not seem to have been a topic of interest to meat scientists" (Warriss, pers. comm.; see Warriss, 2000).

Nevertheless, considerable pertinent information is available. In this paper, we review current evidence concerning the effects of cooking on the net energy value of the diet. We consider plant and animal foods separately, since the mechanisms by which cooking influences net energy value differ for starch, protein and lipid. 


\section{Energetic effects of cooking plant foods}

We define cooking as the use of heat to prepare food. From hunter-gatherers to industrialized society, many plant foods are routinely eaten without being cooked, especially low-starch, high-sugar items such as ripe fruits. For example, among foods eaten by Australian aborigines, the proportion of fruit species that were cooked (sometimes or invariably) was $13.4 \%(\mathrm{n}=97$ species) (tallied from data in Isaacs, 1987). By contrast, starchy foods, such as cereals, tubers and legumes, are mostly eaten after they are cooked (e.g. Australian aborigines: roots $94.1 \%, \mathrm{n}=51$ species; nuts $87.5 \%, \mathrm{n}=16$ species; seeds $84.4 \%, \mathrm{n}=45$ species; tallied from data in Isaacs, 1987). Starchy foods are important for humans since in almost all societies starchy foods are the predominant staples for much of the year (Miller, 1980; FAO/WHO, 1998; Atkins and Bowler, 2001). Two kinds of evidence indicate that cooking of starchy foods leads to substantial increases in net energy value: (1) compromised physiological performance among raw-foodists; and (2) increased digestibility of cooked starch.

Compromised physiological performance among raw-foodists 
Humans on vegetarian diets gain more weight and exhibit higher reproductive performance when eating cooked food than raw food. Table 2 reviews studies showing that vegetarians eating cooked diets have higher Body Mass Index (BMI) than those eating predominantly raw food. Across these studies, the median BMI of healthy adults eating cooked vegetarian diets was 23.7 (women) and 24.3 (men), compared to 20.1 (women), 20.7 (men) and 20.6 (mixed-sex sample) for individuals eating predominantly raw vegetarian diets. Importantly, the higher the proportion of raw food in the diet and the longer the history of raw-foodism, the lower the BMI (Koebnick et al., 1999). The low BMI of individuals eating predominantly raw diets was not due to their being vegetarian, because the BMI of vegetarians eating cooked diets is close to the BMI of those eating typical American mixed diets [BMI for adults eating typical mixed diets: 24.8 (women), 25.3 (men), medians from Table 2]. Furthermore, Koebnick et al. (1999) found that incorporating meat into the diet had no noticeable effect on the energy status of people eating predominantly raw food: odds of being underweight were statistically indistinguishable across vegan, vegetarian, and meat-eating diet groups. 
The raw-foodists represented in Table 2 chose a raw-food lifestyle, an option that tends to be made with the intention of improving health or reducing body weight (Hobbs, 2005). It is therefore possible that the raw-foodists had low BMI because of their determination to ingest few calories, rather than because they ate raw food. However, when Douglass et al. (1985) changed the food of 32 patients with hypertension from a cooked diet to one that averaged $62 \%$ of calories from raw food, body weight fell by an average of $3.8 \mathrm{~kg}$ over 6.7 months. Those eating raw food for more months lost more weight (mean of $6.4 \mathrm{~kg}$ lost for patients eating raw food for $>4$ months). Many raw-foodists apparently do not limit their food intake, since they commonly describe themselves as experiencing persistent hunger despite eating frequently (Wrangham, 2009).

Evidence of low energy intake in women eating predominantly raw food is supported by their having higher rates of amenorrhea or menstrual irregularities than those eating cooked food. Koebnick et al. (1999) found that menstruation was absent in 23\% of females of child-bearing age who ate at least $70 \%$ of their food raw, and in $50 \%$ of women reporting a $100 \%$ raw diet. Although these women were primarily vegetarian, the addition of raw meat to the diet did not change the odds of ovarian suppression (Koebnick et al., 1999). By contrast, patterns of ovarian cycling in vegetarian women on cooked diets show no evidence of disturbance compared to women on diets that include cooked meat (Barr, 1999). Likewise, there is no difference in age of menarche between women eating cooked diets that are vegetarian or include meat (Rosell et al., 2005). The poor ovarian performance of raw-foodists therefore cannot be attributed to their vegetarianism. Koebnick et al. (1999) concluded that women suffered because of their relatively low net energy gain as a consequence of eating their food raw. 
We have found no records of individuals tending to gain weight while eating raw diets, even though the plant foods eaten by raw-foodists are mostly high-quality items such as germinated seeds, sprouts, fruits, nuts and cereals, and tend to include oil (Hobbs, 2005). This is especially surprising since raw-foodists are typically members of urban communities, where habitual activity levels are lower than observed in traditional communities of hunter-gatherers or pastoralists. Furthermore, although raw-foodists are averse to cooking, they typically process their foods extensively by such methods as grinding, pounding, sprouting and pressing, and even heating up to $48^{\circ} \mathrm{C}$ (Koebnick et al., 1999). A nutritional analysis suggested that on a diet of raw wild foods, which are generally lower in energy value and higher in fiber, energy intake in traditional communities would be so limited as to render survival and reproduction difficult (Wrangham and Conklin-Brittain, 2003).

$\underline{\text { Increased digestibility of cooked starch }}$ 
Although raw starch was once thought to be digested completely within the small intestine, for at least two decades it has been known that a significant proportion survives passage through the small intestine (Englyst and Cummings, 1987). Starch that is not digested in the small intestine is called Resistant Starch (RS). RS is important from an energy standpoint because carbohydrates that pass beyond the terminal ileum of the small intestine into the cecum and colon are not digested by the body, but are instead fermented by intestinal microbes (Livesey, 2002). Microbial fermentation generates short-chain fatty acids that yield less energy than the equivalent calories of glucose (the ultimate product of starch hydrolysis in the small intestine), thanks to the less efficient capture of energy as ATP during mammalian oxidation of short-chain fatty acids compared to glucose. In addition, the short-chain fatty acids are a fuel for the microbial flora; and there are further energy losses from production of combustible gases (hydrogen and methane) (Livesey, 1995, 2002; Wiseman, 2006). The result is that RS (and non-starch polysaccharides) delivers only a proportion of its metabolizable energy to the human consumer. This proportion varies among foods and is difficult to measure accurately, but a widely accepted average value for mixed diets is 50\% (Livesey, 1995; Silvester et al., 1995). 
The degree of resistance to digestion of raw starch granules is correlated with their X-ray diffraction pattern, which comes in three types. Type A occurs in cereals. Type B is found in tubers such as potato, and in green bananas. Type C is in legumes. Starches of Types B and C are more resistant than Type A to pancreatic amylase. Cereals thus tend to be more digestible raw than tubers and legumes, but raw starches of all three types have important reductions in digestibility compared to cooked starches. Table 3 gives examples of the impact of cooking and shows that in each case, cooking substantially increases digestibility.

To quantify the increases in digestibility shown in Table 3 we used in vivo assessments of starch digestibility taken from studies of ileostomy patients, i.e. individuals fitted with a bag, or stoma, connected to the terminal ileum (the distal part of the small intestine). Research with ileostomy patients is the most widely used technique for studying starch digestibility because it permits direct quantification of RS. The method is noninvasive for subjects, who simply collect their ileal effluent at regular intervals following a test meal. The most important concern about this method for an accurate assessment of RS is that ileostomy patients can develop higher levels of starch-fermenting bacteria in the terminal ileum than normal, which would lead to the ileal digestibility of starch being overestimated (Champ, 2004). However, ileostomy research has been validated by in vivo studies measuring breath-hydrogen or using direct intubation of the gut (Evenepoel et al., 1998, 1999; Champ, 2004). Table 3 also includes data from in vitro studies, showing that, with appropriate methods, values are close to those obtained in vivo (Muir and O'Dea, 1992; Silvester et al., 1995). 
The figure of $50 \%$ recovery of energy from fermented starch allows us to provide a rough estimate of the energetic consequences of cooking starch. According to data in Table 3 , among humans, the effect of cooking on the ileal digestibility of starch varies from an increase of $28 \%$ for oats to $109 \%$ for green bananas. Assuming that RS fermented in the colon provides $50 \%$ of the calories obtained by digestion in the small intestine, we calculated the digestibility of raw starch by summing its ileal digestibility together with $50 \%$ of the proportion of RS (i.e. $100 \%$ minus ileal digestibility). Comparison with the equivalent digestibility of the same starch cooked reveals the effect of cooking. This method shows that the increased amount of energy provided by cooking varies from $12.1 \%$ for oats to $14.5 \%$ (wheat), 30.2\% (plantain), 30.5\% (potato) and $35.0 \%$ (green banana). A different approach for assessing the impact of cooking was taken by Livesey (1995), whose calculations suggested that increasing the amount of RS has substantial negative effects on body weight. He estimated that an increase in 20 grams of RS in the daily diet would cause a loss in body weight of $\sim 5 \mathrm{~kg}$. 
The mechanism by which cooking increases the digestibility of starch is well understood. Raw starch granules are semi-crystalline mixtures of two carbohydrates, amylopectin and amylose, together with small amounts of lipid and protein. Granules resist hydrolysis by amylases, but application of heat causes a collapse of the semi-crystalline granule structure, a process called gelatinization. Heat also improves digestibility by degrading amylose and denaturing amylase inhibitors (Svihus et al., 2005). Once starch has an amorphous structure it is easily hydrolyzed to sugars and dextrins (Tester et al., 2006). The amount of hydrolysis is intimately related to the extent of gelatinization, which is itself a function of the temperature of processing and the amount of water present (Tester and Sommerville, 2000). The extent of hydrolysis is also dependent on the plant species being eaten, since starch granules from different sources have characteristic patterns of size, shape, structure and composition. For example, digestibility of granules is increased if they are smaller, which partly explains the relative digestibility of different starches (e.g. wheat $>$ maize $>$ pea $>$ potato). Starches are also more easily digested if they contain relatively more amylopectin and less amylose (Tester et al., 2006). 
In addition to cooking (or thermal processing), non-thermal processing can also influence the digestibility of starch. Processing that reduces particle size, such as cracking of wheat grains, increases the in vitro digestibility of raw starch (Heaton et al., 1988).

Other methods of softening, such as grinding and blending, may likewise improve digestibility. For example, poultry fed near-isogenic lines of wheat that are very similar except for hardness experience reduced digestibility when eating harder seeds (Wiseman, 2006). Importantly, however, the starch granules themselves are not made more digestible by physical processing, since they are so small ( 2 - 100 microns diameter) that they are barely damaged even by modern industrial flour mills (Englyst and Englyst, 2005). This means that while non-thermal processing methods, such as grinding and pounding, can increase digestibility to some extent (by reducing particle size), they cannot achieve the large increases in digestibility illustrated in Table 3 that come from cooking (as a result of gelatinization). 
While cooking is well known to increase the digestibility of starch, it might also increase energy availability from plant foods in other ways. First, thermal processing is expected to promote greater digestibility of plant protein and lipids (cf. animal foods, below), as well as some non-starch polysaccharides (e.g. fructans: Wandsnider, 1997). Second, degradation of anti-feedants present in many plant foods should lead to reduced physiological costs (cf. animal foods, below). Third, cooking softens plant items. Heat predictably causes degradation of the pectic polysaccharides that act as an adhesive between plant cell walls, leading to easy separation of cells, a collapse of tissue structure and a loss of firmness (Waldron et al., 2003). As a result, cooked foods are softer, and thus require fewer chewing cycles and a shorter time in the mouth before they form a coherent bolus and are swallowed (Engelen et al., 2005). Soft foods are also associated with reduced costs of digestion, partly because they pass more quickly through the gut (Oka et al., 2003; Secor, in press). The net energetic impact of such mechanisms is unknown. The magnitude of the effects certainly varies by food item and cooking technique, since temperature and moisture both affect the degree of starch gelatinization (McGee, 2004; Tester et al., 2006). Our estimate that cooking leads to an increase in energy gain of 12\%-35\% for various plant starches therefore may not capture the full effects of cooking plant foods.

In sum, quantification of the many different effects of cooking on net energy gain from plant foods remains a remote goal. However the fact that cooking consistently increases the energy value of starchy foods contributes importantly to explaining why humans eating raw foods experience low BMI and impaired reproductive function.

\section{Energetic effects of cooking animal foods}


Meat is an important item in human evolution, but few studies have addressed the potential energetic effects of cooking meat, and in general the literature on the nutritional consequences of cooking animal protein is diffuse and inconsistent. Animal foods consist largely of protein and fat, with a small amount of ash. Protein represents approximately $70 \%$ of muscle tissue by dry matter mass, with relatively higher importance for lean wild meats (USDA 2008). Fat is of lesser importance by mass, representing approximately $25 \%$ of muscle tissue and approximately $90 \%$ of marrow in meats sold in the USA (USDA 2008), but its energy value is disproportionately great owing to the high gross caloric value of lipids $(9 \mathrm{kcal} / \mathrm{g})$ compared to protein $(4 \mathrm{kcal} / \mathrm{g})$ (Merrill and Watt, 1973).

Cooking by dry heat methods, such as roasting, results in fat loss due to dripping (Bender, 1992). Table 4 summarizes fat losses for seven common meats, as reported in the USDA Nutrient Database for Standard Reference (2008), along with their implied reduction in gross caloric value per gram of dry matter compared to raw meat. Reductions in gross caloric value due to cooking were calculated by comparing the reported protein, lipid, carbohydrate and ash contents of raw and cooked samples and multiplying these by the caloric conversion factors of 4, 9, 4 and $0 \mathrm{kcal} / \mathrm{g}$, respectively (Merrill and Watt, 1973). As Table 4 demonstrates, the extent of fat loss can be considerable both in terms of mass and gross caloric value. Based on these data alone, cooking would appear to have negative consequences for the energy value of meat. However, it is not currently known whether the negative effects of cooking on the gross caloric value of meat due to fat loss are outweighed by potential positive effects of cooking on the net energy values of the residual fat and protein, e.g. due to increased intake, increased digestibility, reduced cost of digestion and/or lower basal metabolic expenditure. 
As Table 1 shows, there are various mechanisms by which cooking has been argued to have positive, neutral or negative effects on the net energy value of meat. Given this diversity of possible effects, the question relevant to human evolutionary biology is whether there is a consistent net consequence. The simplest way to find out would be to obtain data on people eating meat-rich diets that differ by whether their meat is raw or cooked. However, no such studies have been reported for humans. Even animal data are lacking. It has been claimed that many experiments show that rats "thrive better on cooked than on raw meat" (Anonymous, 1931), but we have not yet found proof of such research. 
Here, therefore, we review evidence for the impacts of cooking meat on four contributory factors to net energy: food intake, digestibility, the metabolic cost of digestion and basal metabolic rate. We focus mainly on the effects of cooking on whole meat or animal protein rather than animal fat. The purpose is not to suggest that protein was more important than fat in human evolution. Indeed, fat-rich portions of animal carcasses, including brain, bone marrow and adipose tissue, would have been actively utilized whenever possible (Stefansson, 1960; Hayden, 1981; Speth and Spielmann, 1983; Defleur et al., 1999). Archaeological evidence suggests that fat derived from bone marrow may have been preferred over muscle tissue as a source of energy and nutrients among early Homo (Blumenschine, 1991; Blumenschine and Madrigal, 1993). Moreover it is known that diets deriving more than $50 \%$ of calories from lean protein can lead to negative energy balance, so-called "rabbit starvation," due to the high metabolic costs of protein digestion (Speth and Spielmann, 1983; Noli and Avery, 1988) as well as a physiological maximum capacity of the liver for urea synthesis (Speth, 1989; Cordain et al., 2000). Rather, we focus on whole meat or animal protein because virtually no research to date has addressed the impacts of cooking on the energy value of fat. In the nutritional literature, the energy values of different lipids are viewed interchangeably, with discussion focusing instead on fatty acids and their implications for food texture, preservation and health. Nevertheless, we can envisage two ways in which cooking might positively alter the energy value of fat. First, to the extent that cooking heats fat to body temperature or above, less energy will be expended by the body in doing so. Second, the liquefaction of solid fats into oils may increase the surface area of lipid globules exposed to amphipathic (i.e. having both hydrophilic and hydrophobic domains) bile acids in the small intestine, thus promoting 
faster emulsification and ultimately faster absorption. These hypotheses remain to be tested.

Increased food intake

Perhaps not surprisingly, food intake has been shown to vary with palatability (Bobroff and Kissileff, 1986; Yeomans et al., 1997; Yeomans, 1998; de Castro et al., 2000; Stubbs and Whybrow, 2004). Although we have found no studies that specifically investigate differences in intake for ad libitum meat meals served raw and cooked, we find evidence that cooking changes meat texture and flavor in ways that could improve palatability and, by extension, intake. 
Tenderness is the most important determinant of palatability in meat (Bender, 1992; Dransfield, 1994; Huffman et al., 1996; Purslow, 1999; Miller et al., 2001; George-Evins et al., 2004). Yet the effects of cooking on meat tenderness are complex. Meat consists of protein-rich muscle fibers that are interspersed with fat and collagen, a tough connective tissue that derives its strength from a triple-helix arrangement of protein strands. At temperatures above $40^{\circ} \mathrm{C}$, proteins in the muscle fibers begin to denature and coil, producing contraction of the muscle along the grain. This contraction leads to a toughening of the muscle fibers that proceeds with longer cooking time and higher cooking temperature (Barham, 2001; McGee, 2004). Importantly, however, the collagen surrounding each fascicle of muscle fibers generally remains too tough for mastication until heated to $60-70^{\circ} \mathrm{C}$, when collagen begins to be hydrolyzed into gelatin, a soluble protein (Barham, 2001; McGee, 2004). Although the muscle fibers themselves remain tough, meat cooked beyond this temperature can seem more tender because gelatinization of the collagen leads to separation of muscle fibers and the gelatin provides a succulence of its own (Barham, 2001; McGee, 2004). Thus, a trade-off exists between tender muscle fibers and tough collagen at low cooking temperatures and tough muscle fibers and tender collagen at high temperatures. The effects of cooking on meat tenderness therefore depend on the amount of collagen present in the meat, which in turn varies with factors such as species, animal age, muscle type and fat content (marbling) (McGee, 2004; Purslow, 2005; Lepetit, 2008). Collagen-rich meats will require longer cooking and higher temperatures to achieve maximum tenderness whereas meats with lower collagen are best heated rapidly (Barham, 2001). In sum, cooking can lead to palatable improvements in meat texture, provided that samples are cooked properly. 
By contrast, there is little question that cooking consistently improves the flavor of meat. Quintessential "meat" flavor results from the Maillard reaction, a non-enzymatic condensation of amino acids and reducing sugars that proceeds at room temperature but is greatly accelerated by the application of heat (Maillard, 1916). In the process of condensing amino acids and sugars, the Maillard reaction produces mixtures that include brown pigments called melanoidins and a complex variety of aromatic compounds. These intermediates ultimately result in food browning and the development of characteristic aromas and flavors. The importance of the Maillard reaction in producing attractive meat flavors is well known (e.g. Wilson, 1975; Mottram, 2007). For example, a large number of patents have been registered for meat-like flavorants based on the Maillard reaction, beginning with May (1960), who described the production of meat-like flavor by heating cysteine with a reducing sugar (U.S. Patent 2,934,435). Since flavor is the second most important determinant of palatability in meat (Miller et al., 1995; Huffman et al., 1996; Becker et al., 1998), cooking may act to increase intake by producing flavors that boost palatability beyond that accomplished by tenderizing alone. 
The human attraction to certain Maillard compounds poses an interesting conundrum. As will be discussed below, the generation of Maillard reaction products contributes to reducing protein digestibility. Moreover, as precursors to mutagenic heterocyclic amines, Maillard reaction products have been associated with numerous physiological problems, including pancreatic (Anderson et al., 2002), colorectal (Murtaugh et al., 2004; Sinha et al., 2005) and endometrial (Xu et al., 2006) cancers. Why we should be attracted to specific flavors at all remains unknown, but it is particularly surprising that we should demonstrate a distinct preference for flavors associated with apparently detrimental compounds. Moreover, humans do not appear to be alone in this preference. Captive great apes (chimpanzees, bonobos, gorillas, orangutans) presented with a choice of either raw or cooked meat were found to select the cooked samples more often, regardless of neophobic responses to cooked food (Wobber et al., 2008). Although Wobber et al. (2008) did not examine the roles of flavor, texture, or other factors (e.g. post-ingestional experience) in determining preferences, their results suggest that attraction to cooked meat is neither unique to humans nor to species that consume meat. This raises the possibility, suggested by McGee (1990), that humans (and non-human apes) prefer Maillard aromas and flavors because they are chemically similar to volatile compounds naturally present in preferred plant foods.

Increased digestibility 
As with starchy foods, the digestibility of meat must be assessed by ileal rather than fecal measures (e.g. Rutherfurd and Moukghan, 1998). While digestion of fat is nearly complete at the terminal ileum (Jørgensen et al., 2000), a larger portion of protein can escape digestion and pass into the colon. Microbial fermentation of protein in the colon yields amines, ammonia, phenols and other nitrogenous compounds, some of which cross the gut wall and enter the blood stream and urine. However, unlike microbial fermentation of starch, the products of microbial fermentation of protein appear to provide no energy to the consumer (Mason, 1984; McNeil, 1988; Birkett et al., 1996).

The failure of fermented protein to yield energy to the consumer is important because even in typical Western diets, up to $12 \mathrm{~g}$ protein per day can reach the colon undigested (Birkett et al., 1996). Likewise, in animals, ileal protein digestibility is consistently below 100\%, e.g. 63\% - 89\% for rats (Donkoh et al., 1994; Hendriks et al., 2006). The fact that a proportion of food protein is commonly undigested means that, with appropriate processing, its ileal digestibility might in theory be increased. 
The only study of this problem in humans to date has been of protein in eggs laid by chickens eating isotopically labeled diets. Ileostomy patients ate 25 grams of a homogenized mixture of yolk and white, served either raw or microwaved. By monitoring the appearance of labeled proteins in ileal effluent collected from the stoma at regular intervals following a meal, Evenepoel et al. $(1998,1999)$ were able to quantify the ileal digestibility of egg proteins in a manner that was not confounded by endogenous (i.e. nonlabeled) excretion. In addition, they were able to control for the possibility that ileostomates exhibit atypical digestion by first demonstrating that recovery of isotopes in breath was positively correlated with ileal digestibility (Evenepoel et al., 1998) and then establishing that the isotopic recovery profiles of ileostomy patients and intact subjects were comparable (Evenepoel et al., 1999). The ileal digestibility of raw eggs was found to be $51 \%$ in the ileostomy patients and $65 \%$ in healthy volunteers. By contrast, the ileal digestibility of cooked eggs was $91-94 \%$. These data indicate that cooking increased the digestibility of egg protein by $45-78 \%$. This is a striking result considering that chicken egg proteins are commonly treated as having high biological value for humans whether they are consumed raw or cooked. 
Further in vivo studies are needed to establish whether the positive effect on energy value of cooking egg protein, and its magnitude, are typical of other animal proteins, such as those in meat. On one hand, the mechanism attributed by Evenepoel et al. $(1998,1999)$ to explain the increased digestibility of cooked eggs is common to all forms of animal protein: heat-induced denaturation of protein, which acts to make proteins more accessible to proteolytic enzymes (Davies et al., 1987). For this reason we might predict that cooking would make all animal proteins more digestible, as has sometimes been claimed (Lawrie, 1991; Gaman and Sherrington, 1996). On the other hand, there are fundamental differences between animal foods that could potentially influence the effect of cooking on digestibility. For example, the reactivity of human proteases with the protease inhibitors present in animal foods is highly specific and cannot be predicted even across protease inhibitors from the same species. Thus Feeney et al. (1969) found that human trypsin is strongly inhibited by bovine Kunitz pancreatic inhibitor and bovine colostrum inhibitor, but not by bovine Kazal pancreatic inhibitors. The effect of cooking on the reactivity of these inhibitors is, to our knowledge, unknown. It is possible that the effect of cooking may differ even across different types of eggs. For instance, whereas little reaction was found between human trypsin and eleven avian ovomucoids (chicken, golden pheasant, turkey, duck, penguin, cassowary, emu, ostrich, rhea, and tinamou), quail ovomucoid significantly inhibited human enzymatic action (Feeney et al., 1969). Human studies comparing the ileal digestibility of cooked and raw forms of other animal proteins are therefore required to better understand the impact of cooking on protein digestion. 
Among other species, studies have compared the ileal digestibility of protein for cooked and raw forms of meat and bone meal (MBM), a product of the rendering industry that is commonly used to supplement the amino acid profiles of animal feeds. MBM consists of highly processed substances that are liable to have experienced prior denaturation of proteins, thus MBM is not an ideal model for whole meat. However, it is instructive that these studies generally report that ileal digestibility of MBM is reduced by cooking. Among dogs, for example, Johnson et al. (1998) found the ileal digestibility of MBM to be inversely correlated with processing temperature. Among roosters, Johns et al. (1987) found negative effects of cooking time on ileal digestibility of MBM heated at $150^{\circ} \mathrm{C}$ for $1,1.5,3,4$, and 5 hours. These results, which conflict with those for egg protein, suggest that the effect of cooking on protein digestibility may ultimately depend, like tenderness, on the type of protein as well as the cooking method (Borowski et al., 1986; Wang and Parsons, 1998; Goldberg et al., 2004). 
A final challenge to the hypothesis that cooking increases the digestibility of meat is the inhibitory effect of Maillard reaction products on protein digestibility. The heatcatalyzed condensation reaction consumes amino acids, making them unavailable for digestion. Thus the presence of Maillard reaction products has been implicated in lowering protein digestibility in Western diets (AlKanhal et al., 2001; Seiquer et al., 2006). For example, Seiquer et al. (2006) found that consumption of a diet rich in a Maillard reaction product (3.87 mg/kg hydroxymethylfurfural) led to $47 \%$ higher fecal nitrogen excretion and $6 \%$ lower total nitrogen digestibility than a calorie- and macronutrient-matched diet containing a lower concentration of the same product $(0.94 \mathrm{mg} / \mathrm{kg})$. It is believed that the Maillard reaction affects protein digestibility partly by destroying essential amino acids (Moughan et al., 1996; Rerat et al., 2002), inducing structural changes in protein that prevent normal enzymatic cleavage (Kato et al., 1986; Oste and Sjodin, 1984), impeding epithelial transport (Shorrock and Ford, 1978), and actively inhibiting digestive enzymes (Oste et al., 1986, 1987; Rudloff and Lonnerdal, 1992). Nevertheless, to our knowledge, the impact of Maillard reaction products on ileal, rather than fecal, digestibility has not yet been evaluated. Therefore the true relevance of this reaction to human biology remains unknown, especially in the comparison of raw and cooked natural products. 
In sum, no consensus has been reached regarding the effects of cooking on the digestibility of meat. The diversity of outstanding questions concerning protein source, enzyme-specific interactions, and the role of Maillard reaction products indicate the need for direct evaluations of the ileal digestibility of cooked and raw meats in human subjects. However, the most biologically relevant study we have found to date, that reported by Evenepoel et al. $(1998,1999)$, suggests that cooking should have positive impacts on meat digestibility that would not be evident from extant studies based on fecal measures.

\section{$\underline{\text { Lower costs of digestion }}$}

The cost of digestion (also commonly referred to as diet-induced thermogenesis, specific dynamic action or the thermic effect of feeding) stems from numerous metabolic

processes involved the digestion, absorption and excretion of ingested nutrients, including muscular activity and the production of acid and proteolytic enzymes needed to reduce food to usable elements (McCue, 2006; Secor, in press). Although no direct evidence is available for humans, cooking is expected to reduce the metabolic costs of digesting meat. This hypothesis is based on three points.

First, meat proteins are costly to digest. Halton and $\mathrm{Hu}$ (2004) found that for humans the typical cost of digesting protein is $20-35 \%$ of the energy consumed, compared to $5-15 \%$ for carbohydrate and the same or less for fat. Because meat proteins have a high cost of digestion, there is an opportunity for those costs to be meaningfully reduced. 
Second, as discussed above, cooking can tenderize meat if done properly. In other animals the cost of digesting food is reduced when its physical structure is more easily broken down. It has been shown among reptiles and amphibians that food items that are softer induce a lower cost of digestion (Secor and Faulkner, 2002; Secor, 2003; Secor and Boehm, 2006; Boback et al., 2007). For example, Secor and Faulkner (2002) compared the metabolic costs of digestion among marine toads (Bufo marinus) fed meals that differed in hardness. They found that soft-bodied prey items (earthworms and juvenile rats) were associated with $39 \%$ lower costs of digestion, on average, than hard-bodied prey items (superworms and crickets). In mammals, the effect of softness on the cost of digestion has not been studied with respect to meat. However, Oka et al. (2003) found that softening food pellets by the addition of air pockets led to reduced postprandial rises in body temperature. Over time, differences in the cost of digestion led to greater weight gain and adiposity among soft-fed versus hard-fed animals, despite caloric intake and levels of physical activity that were indistinguishable between the two groups. These effects predict that because cooking can reduce the structural integrity of meat, eating cooked meat will involve a lower cost of digestion than eating raw meat. 
Finally, our experiments with Burmese pythons (Python molurus) directly support the hypothesis that cooked meat involves lower digestive costs. Boback et al. (2007) fed size-matched pythons meals of beef sirloin weighing $25 \%$ of the snake's body mass, served in one of four forms: raw and whole; raw and ground; cooked and whole; and cooked and ground. Oxygen consumption was measured at $30^{\circ} \mathrm{C}$ by closed-circuit respirometry before feeding to establish basal levels and after feeding until oxygen consumption returned to basal levels, typically 10-14 days post-feeding. The cost of digestion was quantified from the cumulative postprandial oxygen consumption above standard metabolic rate. We found that cooking reduced the cost of digestion by $12.7 \%$ of meal energy, grinding reduced the cost by $12.4 \%$, and the effects of cooking and grinding were nearly additive, with the cooked and ground meal associated with a $23.4 \%$ reduction compared to the raw and whole treatment. 
Pythons were used in this study because (a) body temperature and activity could be strictly controlled, (b) the ability to feed a large meal made it easier to detect experimental effects with basic respirometry equipment, and (c) infrequent feedings permitted the entire postprandial response to be captured without the confounding effects of a subsequent meal. How closely the results for pythons apply to human costs of digestion is unknown, but there are reasons to believe that the differences could be profound, even apart from the fact that metabolic demands differ between poikilothermic and homeothermic animals. For example, pythons typically ingest their meals whole, necessitating greater gastric effort to break down meals into a soup-like chyme suitable for passage into the small intestine (Secor, 2003). In addition, pythons, unlike humans, exhibit substantial gastrointestinal remodeling between meals (Secor and Diamond 1995, 1997). Secor and Diamond (1995) report several physiological changes in pythons within 1-3 days post-feeding, including a doubling of the mass of the small intestine, growth in other organs involved in digestion and support of metabolism (i.e. stomach, lungs, heart, liver, and kidneys), a 6- to 26-fold increase in intestinal nutrient uptake rate, and an 11- to 24-fold increase in nutrient uptake capacity. Jointly, these responses result in a python experiencing a 17-fold increase in metabolic rate as a result of consuming a typical meal, a response similar to that of a human running at maximum speed.

For these reasons, it would be useful to validate the effects of cooking and grinding on the cost of digestion in humans. Although experimentally more challenging due to the confounding variables of activity expenditure and body temperature regulation, metabolic chambers have been used successfully to estimate 24-hour cost of digestion in humans (Westerterp et al., 1999). 


\section{Lower costs of defense}

Cooking kills foodborne bacteria, including strains associated with raw meat products such as Escherichia coli, Salmonella, Campylobacter, Staphylococcus and Listeria. If ingested live, these pathogens result in upregulation of the immune system, typically involving fever, with measurable results. Among adults, fever has been shown to increase basal metabolic rate (BMR) by approximately $13 \%$ for each $1{ }^{\circ} \mathrm{C}$ above standard temperature (DuBois, 1937). Similarly, in a study among Gambian children with malaria, Stettler et al. (1992) found that resting energy expenditure was highly correlated with degree of fever, increasing $6.9 \%$ for each $1{ }^{\circ} \mathrm{C}$ above standard temperature. Cooking meat may thus lower average metabolic rate by reducing the costs of immune maintenance and upregulation.

The potential energy savings due to reduced immune maintenance and upregulation could be sizeable. With customary cooking, the lifetime energetic cost due to bacterial infection is very small. Table 5 shows the annual number of illnesses, assumed degree and mean reported duration of fever given infection, and resulting annual cost from infection by E. coli O157:H7, Salmonella, Campylobacter and Listeria when cooking is customary. Annual illnesses were derived from CDC estimates of the number of yearly cases (both reported and unreported) in the U.S., multiplied by CDC estimates of the proportion of cases specifically attributable to foodborne transmission, divided by 267.7 million, the U.S. resident population as of 1997 (Mead et al., 1999). Let us further assume that the cost of upregulation is $13 \%$ of $\mathrm{BMR}$ for each $1^{\circ} \mathrm{C}$ of temperature above standard, as was demonstrated by DuBois (1937). With these assumptions, the annual cost of immune upregulation due to fever is only $0.01 \mathrm{x}$ daily BMR. Over a hypothetical lifetime of 75 
years, this is equivalent to less than one day's worth of basal metabolism. By contrast, without customary cooking, the energetic cost of bacterial infection appears to be much higher. Table 6 shows the estimation of annual illnesses on a raw diet, based on (a) USDA estimates of the percentage of U.S. beef, pork, mutton and/or poultry market products infected with each bacteria (Beran, 1995), (b) the number of meals of each meat consumed per capita, where the number of meals was determined by dividing U.S. per capita consumption of beef, pork, mutton and/or poultry (USDA, 1999) by an assumed serving size of $0.25 \mathrm{~kg}$ of meat (pre-cooking) per meal, and (c) an assumed transmission rate of $10 \%$ (i.e. consumption of an infected market product would result in illness $10 \%$ of the time), which is unknown but probably conservative since very low counts of these pathogens are required to cause illness. Based on these assumptions, and following a calculation analogous to that shown in Table 5, a consumer is expected to fall ill 42 times per year and suffer from elevated body temperature on 145 days out of the year. The annual cost of immune upregulation due to fever in this case would be a staggering $33.7 \mathrm{x}$ daily BMR, or 6.9 years worth of basal metabolism over a 75-year lifetime. Raw wild meat is possibly less pathogen-bearing on average than raw meat that has been raised and processed for mass-market consumption. Our calculation is thus necessarily rough, but it suggests that meat consumption at Western levels would be energetically inefficient in the absence of cooking. 


\section{Effect of cooking on meat energy}

Our review of the diffuse and largely indirect literature suggests several mechanisms by which cooking might increase the energy available from meat. These include increasing food intake through positive effects on palatability related to texture and flavor, rendering proteins more digestible through denaturation, lowering the cost of digestion through food softening, and reducing immune upregulation by eliminating foodborne pathogens. It is, however, difficult to draw definitive conclusions about the net energetic effects of cooking from studies focused at the sub-component level (e.g. digestibility or cost of digestion) because the components themselves may interact. For example, we might predict that the lower the digestibility of a food with a given macronutrient composition, the lower its cost of digestion, because the cost of digestion includes expenditures due to absorption and post-absorptive processes like deamination, ketogenesis and protein synthesis. Moreover, we do not know whether the combined effects on intake, digestibility, cost of digestion and basal metabolism are sufficient to counteract reductions in the gross caloric value of meat due to fat loss arising from cooking. Controlled studies of growth or energy balance on cooked and raw meat-rich diets will be required to better understand the effects of cooking and the mechanisms involved.

Collection of longitudinal anthropometric and ovarian data among raw-foodists incorporating different quantities of raw meat, different forms of raw food processing, and different raw-to-cooked fractions in their diets would be especially useful. 


\section{The impact of cooking on human evolution}

Among humans and non-human great apes, even small improvements in energy balance confer significant advantages on survival and reproductive success (Ellison et al., 1993; Knott, 2001; Ellison, 2003; Emery Thompson et al., 2007; Emery Thompson and Wrangham, 2008). The more that food processing increases net energy gain, therefore, the greater its expected effects on human evolutionary biology.

Unfortunately, the time when human ancestors first practiced thermal food processing has not been identified using archaeological data, because the record of the control of fire does not exhibit any threshold pattern distinguishing periods of use and nonuse. The problem is that traces of fire normally disappear rapidly: even as recently as the Mesolithic, fireplaces can be invisible (Sergant et al., 2006). Nevertheless fire was certainly controlled by 250 kya (James, 1989). Further back in time, few people would reject evidence for control of fire at 400 kya from such sites as Beeches Pit (Gowlett et al., 2005; Preece et al., 2006), Schöningen (Thieme, 2000; Thieme, 2005), and Ménez-Drégan (Monnier et al., 1994). Evidence for control of fire is also impressive at 790 kya at Gesher Benot Ya'aqov on the Jordan River (Goren-Inbar et al., 2004; Alperson-Afil, 2008), and there are several African sites older than 1 mya where control of fire has been reported as plausible or likely (Wrangham, 2006). But the interpretation of these older sites is open to question (James, 1989). As a result of the way the evidence dwindles erratically in the past, archaeological data currently offer no certainty when fire was first controlled. 
Anatomical adaptations provide an alternative means to infer when cooking began. The poor performance of humans eating both raw vegetarian and raw omnivorous diets (e.g. Koebnick et al., 1999) suggests that our species is biologically adapted to the consumption of cooked food; and importantly, some of the features preventing humans from utilizing raw food efficiently include traits recognizable in fossils, i.e. small molars and relatively small total gut volume (Wrangham and Conklin-Brittain, 2003; Lucas, 2004).

Based on anatomical adaptations, cooking has been proposed to begin with Homo erectus (Wrangham et al., 1999; Wrangham, 2006). Fossils of H. erectus exhibit reduced postcanine dentition compared to earlier hominins (Wood and Aiello, 1998) as well as markers of reduced masticatory strain such as facial shortening (Lieberman et al., 2004), implying a softer diet than in earlier hominins. The unflared, barrel shape of the thoracic cage and the narrow dimension of the pelvis in H. erectus also indicate a small gut (Aiello and Wheeler, 1995), suggesting a diet of higher digestibility. Despite these anatomical constraints, H. erectus shows signals of increased energy use compared to Homo (Australopithecus) habilis, including larger body and relative brain size (Leonard and Robertson, 1994; Ruff et al., 1997; Aiello and Wells, 2002), a suite of locomotor adaptations that improve the human capacity for long-distance running (Bramble and Lieberman, 2004), and possibly reduced interbirth intervals (Aiello and Key, 2002). The apparently softer, more digestible and higher energy diet of $H$. erectus is consistent with the expected effects of cooking (Wrangham, 2006). 
Among hypotheses attempting to understand the relationship between diet and human evolutionary anatomy, the principal alternative to cooking originating with $H$. erectus is that the signs of increased energy gain in $H$. erectus indicate a diet of increased meat, rather than cooking (Washburn and Lancaster, 1968; Shipman and Walker, 1989; Aiello and Wheeler, 1995). Under this scenario, the origin of cooking has instead been ascribed to Homo heidelbergensis, since $H$. heidelbergensis exhibits the largest subsequent signal of increased diet quality: a further increase in relative brain size beginning 450 kya (Aiello and Wheeler, 1995). We see three problems with this hypothesis. First, the small teeth and reduced guts ascribed to H. erectus are not easily compatible with a raw diet. For instance, if $H$. erectus relied partly on raw plant items, large guts would have been required for fermenting structural carbohydrates. Second, since cooking appears to have significant effects on energy gain as well as on food texture, the anatomical changes from $H$. erectus to $H$. heidelbergensis appear too small to be comfortably associated with the origin of cooking. Third, if a rise in meat eating accounts for the origin of H.erectus, the origin of H. (A.) habilis is a puzzle. Cut marks on prey species are evident from 2.5 mya onwards, suggesting a transition in the importance of meat attributable to $H$. (A.) habilis or their immediate ancestors (Toth and Schick, 2006). A possible solution is that the increase in meat eating began with scavenging in $H$. (A.) habilis and continued with hunting in $H$. erectus, but there are difficulties with that idea (O'Connell et al., 2002). 
Key problems for the hypothesis that cooking originated with $H$. erectus include the relative merits of non-thermal and thermal food processing, and the complex evolutionary relationship between $H$. (A.) habilis and H. erectus. First, might non-thermal processing account for the evolutionary changes seen in H. erectus, i.e. reduced tooth size, smaller jaws, reduced gut size and increased energy use? Since chimpanzees use various nonthermal processing techniques, relatively elaborate forms of such processing presumably preceded cooking. For example, wild chimpanzees pound the stems of oil palm (Elaeis guineensis) to soften them (Yamakoshi and Sugiyama, 1995); invariably chew raw meat with tough leaves that apparently have no nutritional value, possibly to accelerate comminution (Goodall, 1986); soak fruits in water (Boesch and Boesch-Achermann, 2000); and in captivity, mash fruits to soften them (Fernández-Carriba and Loeches, 2001). Hunter-gatherers employ more elaborate non-thermal processing techniques, including caching meat or fish to allow it to rot (Jenness, 1922; Pálsson, 2001); grinding seeds (Driver, 1961); burying fruits in sand to soften them (Isaacs, 1987); making an edible raw dough by mixing crushed seeds and water (Isaacs, 1987); sun-drying meat, which likely increases digestibility via denaturation (Driver, 1961); and pounding tubers, fruits or meat (Driver, 1961; Tanaka, 1980; Isaacs, 1987; Pálsson, 2001). Pounding is of particular interest because it theoretically provides many of the same physical benefits as cooking. For example, it reduces the particle size of raw plant items, leading to improved digestibility (Heaton et al., 1988). (However, pounding still leaves starch granules intact; and it does not promote gelatinization). It can also act to tenderize meat (Glover et al., 1977; Mandigo and Olson, 1982), potentially leading to improved palatability, increased digestibility and reduced costs of digestion, as discussed above. The advent of efficient 
pounding as a method of improving food quality might therefore have led to important increases in energy availability.

However, the evidence from urban raw-foodists, who exhibit low energy status despite extensive use of sophisticated non-thermal processing techniques (Hobbs, 2005), clearly suggests that cooking provides critical energetic benefits beyond those afforded by non-thermal processing alone. This is not surprising, given that heat greatly facilitates the gelatinization of starch, denaturation of proteins (including collagen), and killing of foodborne pathogens. This provides a further reason why the energetic transition associated with $H$. erectus, which is uniquely large compared to transitions involving any subsequent human species (Aiello and Key, 2002; Aiello and Wells, 2002; Wrangham, 2006), is best ascribed to the adoption of cooking, and not solely to non-thermal processing.

The second problem for the proposed association of $H$. erectus with cooking is that H. erectus and $H$. (A.) habilis have a complex relationship that includes a temporal overlap in East Africa of around half a million years ( 1.9 to 1.44 mya; Spoor et al., 2007), and a less clear distinction in body mass and relative brain size than formerly thought (Spoor et al., 2007; Lordkipanidze et al., 2007; Lieberman, 2007). For instance some anatomically defined $H$. erectus in Georgia are in the size range of $H$. (A.) habilis, and in Kenya have a relative brain size similar to $H$. (A.) habilis. Additional fossil data are needed to clarify the relationships among these highly variable populations. Our analysis raises the possibility, however, that differences in the extent and technologies of non-thermal processing might explain some of the variation. 
In the Lower Paleolithic, spheroids could have been exploited as pounding instruments. The effectiveness of such tools for food processing has not yet been evaluated because Oldowan hammerstones are typically assumed to have been used for smashing or flaking, rather than for pounding food (Schick and Toth, 1994; de Beaune, 2004; Mora and de la Torre, 2005). Hammerstones are numerous in the fossil record during the period of overlap between H. (A.) habilis and H. erectus (Mora and de la Torre, 2005) and offer obvious possibilities for both species to have actively increased the energy value of food by physical means.

Ultimately, studies of the relative energetic impacts of cooking and non-thermal processing for plant and animal foods will be required to better discriminate the developments in food processing technology attributable to H. (A.) habilis, H. erectus and $H$. heidelbergensis, as well as to quantify the role of these technologies in supporting energetic requirements both during the evolution of Homo and as they exist today.

\section{Conclusion}


Much research is devoted to the strategies used by humans and our closest relatives to meet daily energy requirements. Surprisingly, however, the effects of cooking have only recently begun to be discussed in this respect (Aiello and Wheeler, 1995; Wrangham et al., 1999; Wrangham and Conklin-Brittain, 2003; Wrangham, 2006) and very little is still known about how this unique and universal human technology affects energy balance. Here we have reviewed evidence pertinent to the hypothesis that an important and consistent effect of cooking food is a rise in its net energy value. We find strong support for positive impacts of cooking on plant foods. Studies reflecting compromised body mass and reproductive ability among individuals who follow a predominantly vegetarian, predominantly raw diet suggest that cooking is imperative in humans for the efficient extraction of energy from plant foods, even when those foods have been agriculturally modified and extensively processed by non-thermal methods. A critical mechanism appears to be the effect of heat on the physicochemical properties of starch molecules, leading to substantially improved digestibility. The evidence for meat is more equivocal. Few studies have directly compared raw and cooked meat with respect to energy, and results among the few studies that do exist are often contradictory, thus necessitating inferences based on indirect and imperfect data. We find support for positive impacts of cooking with respect to food intake, digestibility, cost of digestion and basal metabolism. However, it is not yet known whether the combined positive effects on these factors are sufficient to overcome reductions in the gross caloric value of meat due to fat loss arising from cooking. Given that textural changes are at least partially responsible for the proposed positive effects of cooking on intake, digestibility and the cost of digestion, non-thermal processing methods 
that manipulate texture, such as pounding, may likewise be effective in improving the net energy value of meat.

Our data suggest that if non-thermal processing methods like pounding were used by early Homo then they likely provided an important increase in energy gain over unprocessed raw diets. This increase may have contributed to the support of energetically expensive adaptations first emerging in $H$. (A.) habilis, such as increased body and relative brain size. We observe, however, that cooking contributes additional benefits that are not readily achieved with non-thermal processing, including the gelatinization of starch, denaturation of proteins, and killing of foodborne pathogens. Although the earliest unequivocal hearths date only to around 250 kya (James, 1989), earlier dates for the control of fire cannot be rejected archaeologically. Since cooking should have been evolutionarily significant, and since the energetic and textural impacts of cooking appear consistent with morphological adaptations signaling high dietary quality in $H$. erectus, the hypothesis that cooking began with $H$. erectus remains viable. Additional studies of the net energetic benefits of consuming plant and animal foods when raw, processed by nonthermal methods, and/or cooked will make great strides toward isolating the unique contributions of cooking in human evolution. 


\section{Acknowledgments}

We are grateful to W.C. McGrew and Robert Foley for the invitation to participate in this special issue. We thank Susan Antón, Nancy Lou Conklin-Brittain, Victoria Ling,

Geoffrey Livesey, Peter Lucas, Charles Nunn, Stephen Secor, John Slyconish, Katherine Zink and three anonymous reviewers for useful comments and discussion. 


\section{References}

Aiello, L., Wheeler, P., 1995. The expensive-tissue hypothesis: the brain and the digestive system in human and primate evolution. Current Anthropology 36, 199-221.

Aiello, L.C., Key, C., 2002. Energetic consequences of being a Homo erectus female. American Journal of Human Biology 14, 551-565.

Aiello, L.C., Wells, J.C.K., 2002. Energetics and the evolution of the genus Homo. Annual Review of Anthropology 31, 323-338.

AlKanhal, H.A., Al-Othman, A.A., Hewedi, F.M., 2001. Changes in protein nutritional quality in fresh and recombined ultra high temperature treated milk during storage. International Journal of Food Sciences and Nutrition 52, 509-514.

Alperson-Afil, N., 2008. Continual fire-making by hominins at Gesher Benot Ya'aqov, Israel. Quaternary Science Reviews 27, 1733-1739.

Alperson-Afil, N., Goren-Inbar, N., 2006. Out of Africa and into Eurasia with controlled use of fire: evidence from Gesher Benot Ya'aqov, Israel. Archaeology, Ethnology \& Anthropology of Eurasia 4, 63-78.

Anderson, K.E., Sinha, R., Kulldorff, M., Gross, M., Lang, N.P., Barber, C., Harnack, L., DiMagno, E., Bliss, R., Kadlubar, F.F., 2002. Meat intake and cooking techniques: associations with pancreatic cancer. Mutation Research 506, 225-231.

Anonymous, 1931. Digestibility of raw and cooked meat. Lancet February 21, 422. Atkins, P., Bowler, I., 2001. Food in Society: Economy, Culture, Geography. Arnold, London.

Barham, P., 2001. The Science of Cooking. Springer, Berlin. 
Barr, S.I., 1999. Vegetarianism and menstrual cycle disturbances: is there an association? American Journal of Clinical Nutrition 70, 549S-554S.

Becker, T., Benner, E., Glitsch, K., 1998. Summary report on consumer behaviour towards meat in Germany, Ireland, Italy, Spain, Sweden and the United Kingdom: results of a consumer survey. Department of Agricultural Policy and Agricultural Economics, University of Hohenheim, Stuttgart.

Bender, A., 1992. Meat and meat products in human nutrition in developing countries. Food and Agriculture Organization of the United Nations, Food and Nutrition Paper No. 53.

Beran, G., 1995. Tracking foodborne pathogen data from farm to retail: comments. United States Department of Agriculture, Economic Research Service, Miscellaneous Publication No. 1532.

Birkett, A., Muir, J., Phillips, J., Jones, G., O'Dea, K., 1996. Resistant starch lowers fecal concentrations of ammonia and phenols in humans. American Journal of Clinical Nutrition 63, 766-772.

Blumenschine, R.J., 1991. Hominid carnivory and foraging strategies, and the socioeconomic function of early archaeological sites. Philosophical Transactions of the Royal Society of London, Series B 334, 211-221.

Blumenschine, R.J., Madrigal, T.C., 1993. Variability in long bone marrow yields of East African ungulates and its zooarchaeological implications. Journal of Archaeological Science 20, 555-587. 
Boback, S.M., Cox, C.L., Ott, B.D., Carmody, R., Wrangham, R.W., Secor, S.M., 2007.

Cooking reduces the cost of meat digestion. Comparative Biochemistry and

Physiology, Part A 148, 651-656.

Bobroff, E.M., Kissileff, H.R., 1986. Effects of changes in palatability on food-intake and the cumulative food-intake curve in man. Appetite 7, 85-96.

Bodwell, C.E., Anderson, B.A., 1986. Nutritional composition and value of meat and meat products. In: Bechtel, P.J. (Ed.), Muscle as Food. Academic Press, London, pp. $321-371$.

Boesch, C., Boesch-Achermann, H., 2000. The Chimpanzees of the Taï Forest: Behavioral Ecology and Evolution. Oxford University Press, New York, NY.

Borenstein, B., Lachance, P.A., 1988. Effects of processing and preparation on the nutritive value of foods. In: Shils, M.E., Young, V.R. (Eds.), Modern Nutrition in Health and Disease. Lea and Febiger, Philadelphia, PA, pp. 672-684.

Borowski, J., Kozikowski, W., Rotkiewicz, W., Amarowicz, R., 1986. Influence of cooking methods on the nutritive-value of turkey meat. Nahrung-Food 30, 987-993.

Brace, C.L., 1995. The Stages of Human Evolution. Prentice-Hall, Englewood Cliffs, NJ. Bramble, D.M., Lieberman, D.E., 2004. Endurance running and the evolution of Homo. Nature 432, 345-352.

Brown, M.A., Storlien, L.H., Brown, I.L., Higgins, J.A., 2003. Cooking attenuates the ability of high-amylose meals to reduce plasma insulin concentrations in rats. British Journal of Nutrition 90, 823-827.

Champ, M.M.J., 2004. Physiological aspects of resistant starch and in vivo measurement. Journal of AOAC International 87, 749-755. 
Charley, H., 1982. Food Science. Wiley, New York, NY.

Cordain, L., Miller, J.B., Eaton, S.B., Mann, N., Holt, S.H.A., Speth, J.D., 2000. Plantanimal subsistence ratios and macronutrient energy estimations in worldwide huntergatherer diets. American Journal of Clinical Nutrition 71, 682-692.

Davies, K.J.A., Lin, S.W., Pacifici, R.E., 1987. Protein damage and degradation by oxygen radicals. IV. Degradation of denatured protein. Journal of Biological Chemistry 262, 9914-9920.

de Beaune, S., 2004. The invention of technology: prehistory and cognition. Current Anthropology 45, 139-162.

de Castro, J.M., Bellisle, F., Dalix, A.M., 2000. Palatability and intake relationships in free-living humans: measurement and characterization in the French. Physiology \& Behavior 68, 271-277.

Defleur, A., White, T., Valensi, P., Slimak, L., Crégut-Bonnoure, E., 1999. Neanderthal cannibalism at Moula-Guercy, Ardèche, France. Science 286, 128 - 131.

Donaldson, M.S., 2001. Food and nutrient intake of Hallelujah vegetarians. Nutrition and Food Science 31, 293-303.

Donkoh, A., Moughan, P.J., Smith, W.C., 1994. True ileal digestibility of amino acids in meat and bone meal for the growing pig: application of a routine rat digestibility assay. Animal Feed Science and Technology 49, 73-86.

Douglass, J.M., Rasgon, I.M., Fleiss, P.M., Schmidt, R.D., Peters, S.N., Abelmann, E.A., 1985. Effects of a raw food diet on hypertension and obesity. Southern Medical Journal $78,841-844$. 
Dransfield, E., 1994. Tenderness of meat, poultry and fish. In: Pearson, A.M., Dutson, T.R.

(Eds.), Quality Attributes and Their Measurements in Meat, Poultry and Fish Products. Blackie Academic and Professional, London, pp. 289-315.

Driver, H.E., 1961. Indians of North America. University of Chicago Press, Chicago, IL.

DuBois, E.F., 1937. The Mechanisms of Heat Loss and Temperature Regulation. Stanford University Press, Palo Alto, CA.

Ellison, P., 2001. On Fertile Ground. Harvard University Press, Cambridge, MA.

Ellison, P.T., 2003. Energetics and reproductive effort. American Journal of Human

Biology 15, 342-351.

Ellison, P.T., Panter-Brick, C., Lipson, S.F., O'Rourke, M.T., 1993. The ecological context of human ovarian function. Human Reproduction 8, 2248-2258.

Emery Thompson, M., Kahlenberg, S.M., Gilby, I.C., Wrangham, R.W., 2007. Core area quality is associated with variance in reproductive success among female chimpanzees at Kanyawara, Kibale National Park. Animal Behaviour 73, 501-512.

Emery Thompson, M., Wrangham, R.W., 2008. Diet and reproductive function in wild female chimpanzees (Pan troglodytes schweinfurthii) at Kibale National Park, Uganda. American Journal of Physical Anthropology 135, 171-181.

Engelen, L., Fontijn-Tekamp, A., van der Bilt, A., 2005. The influence of product and oral characteristics on swallowing. Archives of Oral Biology 50, 739-746.

Englyst, H.N., Cummings, J.H., 1986. Digestion of the carbohydrates of banana (Musa paradisiaca sapientum) in the human small intestine. American Journal of Clinical Nutrition 444, 42-50. 
Englyst, H.N., Cummings, J.H., 1987. Digestion of polysacccharides of potato in the small intestine of man. American Journal of Clinical Nutrition 45, 423-431.

Englyst, K.N., Englyst, H.N., 2005. Carbohydrate bioavailability. British Journal of Nutrition 94, 1-11.

Evenepoel, P., Claus, D., Geypens, B., Hiele, M., Geboes, K., Rutgeerts, P., Ghoos, Y., 1999. Amount and fate of egg protein escaping assimilation in the small intesstine of humans. American Journal of Physiology (Gastrointestinal and Liver Physiology) 277, 935-943.

Evenepoel, P., Geypens, B., Luypaerts, A., Hiele, M., Rutgeerts, P., 1998. Digestibility of cooked and raw egg protein in humans as assessed by stable isotope techniques. Journal of Nutrition 128, 1716-1722.

FAO/WHO, 1998. Carbohydrates in human nutrition. Report of a Joint FAO/WHO Expert Consultation, Food and Nutrition Paper No. 66. http://www.fao.org/docrep/W8079E/ w8079e00.htm.

FDA, 2002. Foodborne pathogenic microorganisms and natural toxins handbook. United States Food and Drug Administration, Center for Food Safety and Applied Nutrition. http://vm.cfsan.fda.gov/ mow/intro.html.

Feeney, R.E., Means, G.E., Bigler, J.C., 1969. Inhibition of human trypsin plasmin and thrombin by naturally occurring inhibitors of proteolytic enzymes. Journal of Biological Chemistry 244, 1957-1960.

Fernández-Carriba, S., Loeches, A., 2001. Fruit smearing by captive chimpanzees: a newly observed food-processing behavior. Current Anthropology 42, 143-147. 
Fontana, L., Shew, J.L., Holloszy, J.O., Villareal, D.T., 2005. Low bone mass in subjects on a long-term raw vegetarian diet. Archives of Internal Medicine 165, 684-689.

Friedman, M., 2003. Nutritional consequences of food processing. Forum Nutrition 56, $350-352$.

Gaman, P.M., Sherrington, K.B., 1996. The Science of Food: An Introduction to Food Science, Nutrition and Microbiology. Pergamon Press, Oxford.

George-Evins, C.D., Unruh, J.A., Waylan, A.T., Marsden, J.L., 2004. Influence of quality classification, aging period, blade tenderization, and endpoint cooking temperature on cooking characteristics and tenderness of beef gluteus medius steaks. Journal of Animal Science 82, 1863-1867.

Glover, E.E., Forrest, J.C., Johnson, H.R., Bramblett, V.D., Judge, M.D., 1977. Palatability and cooking characteristics of mechanically tenderized beef. Journal of Food Science $42,871-874$

Goldberg, T., Cai, W.J., Peppa, M., Dardaine, V., Baliga, B.S., Uribarri, J., Vlassara, H., 2004. Advanced glycoxidation end products in commonly consumed foods. Journal of the American Dietetic Association 104, 1287-1291.

Goodall, J., 1986. The Chimpanzees of Gombe: Patterns of Behavior. Harvard University Press, Cambridge, MA.

Goren-Inbar, N., Alperson, N., Kislev, M.E., Simchoni, O., Melamed, Y., Ben-Nun, A., Werker, E., 2004. Evidence of hominin control of fire at Gesher Benot Ya'aqov, Israel. Science $304,725-727$.

Gowlett, J.A.J., 2006. The early settlement of northern Europe: fire history in the context of climate change and the social brain. Comptes Rendus Palevol 5, 299-310. 
Gowlett, J.A.J., Hallos, J., Hounsell, S., Brant, V., Debenham, N.C., 2005. Beeches Pit: archaeology, assemblage dynamics and early fire history of a Middle Pleistocene site in East Anglia, UK. Journal of Eurasian Archaeology 3, 3-40.

Halton, T.L., Hu, F.B., 2004. The effects of high protein diets on thermogenesis, satiety and weight loss: a critical review. Journal of the American College of Nutrition 23, 373385.

Hayden, B., 1981. Subsistence and ecological adaptations of modem hunter/gatherers. In: Harding, R.S.O., Teleki, G. (Eds.), Omnivorous Primates: Gathering and Hunting in Human Evolution. Columbia University Press, New York, NY, pp. 344-421.

Heaton, K.W., Marcus, S.N., Emmett, P.M., Bolton, C.H., 1988. Particle size of wheat, maize, and oat test meals: effects on plasma glucose and insulin responses and on the rate of starch digestion in vitro. American Journal of Clinical Nutrition 47, 675-682.

Hendriks, W.H., Cottam, Y.H., Thomas, D.V., 2006. The effect of storage on the nutritional quality of meat and bone meal. Animal Feed Science and Technology 127, 151-160.

Hobbs, S.H., 2005. Attitudes, practices, and beliefs of individuals consuming a raw foods diet. Explore 1, 272-277.

Huffman, K.L., Miller, M.F., Hoover, L.C., Wu, C.K., Brittin, H.C., Ramsey, C.B., 1996. Effect of beef tenderness on consumer satisfaction with steaks consumed in the home and restaurant. Journal of Animal Science 74, 91-97.

Isaacs, J., 1987. Bush Food: Aboriginal Food and Herbal Medicine. New Holland, Sydney. James, S.R., 1989. Hominid use of fire in the Lower and Middle Pleistocene: a review of the evidence. Current Anthropology 30, 1-26. 
Jenkins, D.J.A., 1988. Nutrition and diet in management of diseases of the gastrointestinal tract. (C) Small intestine. (6) Factors influencing absorption of natural diets. In: Shils, M.E., Young, V.R. (Eds.), Modern Nutrition in Health and Disease. Lea and Febiger, Philadelphia, PA, pp. 1151-1166.

Jenness, D., 1922. Report of the Canadian Arctic Expedition 1913-18. Volume XII: The Life of the Copper Eskimos. F. A. Acland, Ottawa.

Johns, D.C., Low, C.K., Sedcole, J.R., Gurnsey, M.P., James, K.A.C., 1987. Comparison of several in vivo digestibility procedures to determine lysine digestibility in poultry diets containing heat-treated meat and bone meals. British Poultry Science 28, 397-406.

Johnson, M.L., Parsons, C.M., Fahey, G.C., Merchen, N.R., Aldrich, C.G., 1998. Effects of species raw materials source, ash content, and processing temperature on amino acid digestibility of animal by-product meals by cecectomized roosters and ileally cannulated dogs. Journal of Animal Science 76, 1112-1122.

Jørgensen, H., Gabert, V.M., Hedemann, M.S., Jensen, S.K., 2000. Digestion of fat does not differ in growing pigs fed diets containing fish oil, rapeseed oil or coconut oil. Journal of Nutrition 130, 852-857.

Kato, Y., Matsuda, T., Kato, N., Watanabe, K., Nakamura, R., 1986. Browning and insolubilization of ovalbumin by the Maillard reaction with some aldohexoses. Journal of Agricultural and Food Chemistry 34, 351-355.

Knott, C., 2001. Female reproductive ecology of the apes: implications for human evolution. In: Ellison, P. (Ed.), Reproductive Ecology and Human Evolution. Aldine, New York, NY, pp. 429-463. 
Koebnick, C., Strassner, C., Hoffmann, I., Leitzmann, C., 1999. Consequences of a longterm raw food diet on body weight and menstruation: results of a questionnaire survey. Annals of Nutrition and Metabolism 43, 69-79.

Langkilde, A.M., Champ, M., Andersson, H., 2002. Effects of high-resistant-starch banana flour (RS2) on in vitro fermentation and the small-bowel excretion of energy, nutrients, and sterols: an ileostomy study. American Journal of Clinical Nutrition 75, 104-111.

Lawrie, R.A., 1991. Meat Science. Pergamon Press, Oxford.

Leonard, W.R., Robertson, M.L., 1994. Evolutionary perspectives on human nutrition: the influence of brain and body size on diet and metabolism. American Journal of Human Biology 6,77-88.

Leonard, W.R., Robertson, M.L., 1997. Comparative primate energetics and hominid evolution. American Journal of Physical Anthropology 102, 265-281.

Lepetit, J., 2008. Collagen contribution to meat toughness: theoretical aspects. Meat Science 80, 960-967.

Lieberman, D.E., 2007. Homing in on early Homo. Nature 449, 291-292.

Lieberman, D.E., Krovitz, G.E., Yates, F.W., Devlin, M., Claire, M.S., 2004. Effects of food processing on masticatory craniofacial growth in a retrognathic strain and face. Journal of Human Evolution 46, 655-677.

Livesey, G., 1995. The impact of complex carbohydrates on energy balance. European Journal of Clinical Nutrition 49, S89-S96.

Livesey, G., 2002. Thermogenesis associated with fermentable carbohydrate in humans, validity of indirect calorimetry, and implications of dietary thermogenesis for energy 
requirements, food energy and body weight. International Journal of Obesity 26, 1553-1569.

Lordkipanidze, D., Jashashvili, T., Vekua, A., Ponce de León, M.S., Zollikofer, C.P.E., Rightmire, G.P., Pontzer, H., Ferring, R., Oms, O., Tappen, M., Bukhsianidze, M., Agusti, J., Kahlke, R., Kiladze, G., Martinez-Navarro, B., Mouskhelishvili, A., Nioradze, M., Rook, L., 2007. Postcranial evidence from early Homo from Dmanisi, Georgia. Nature 449, 305-310.

Lucas, P., 2004. Dental Functional Morphology: How Teeth Work. Cambridge University Press, Cambridge.

Maillard, L.C., 1916. A synthesis of humic matter by effect of amine acids on sugar reducing agents. Annales De Chimie France 5, 258-316.

Mandigo, R.W., Olson, D.G., 1982. Effect of blade size for mechanically tenderizing beef rounds. Journal of Food Science 47, 2095-2096.

Mason, V.C., 1984. Metabolism of nitrogenous compounds in the large gut. Proceedings of the Nutritional Society 43, 45-53.

May, C.G., 1960. Process for preparing a flavoring substance. U.S. Patent No. 2,934,435.

McCue, M.D., 2006. Specific dynamic action: a century of investigation. Comparative Biochemistry and Physiology, Part A 144, 381-394.

McGee, H., 1990. The Curious Cook: More Kitchen Science and Lore. Macmillan, New York, NY.

McGee, H., 2004. On Food and Cooking: the Science and Lore of the Kitchen. Scribner, New York. 
McNeil, N.I., 1988. Nutritional implications of human and mammalian large intestinal function. World Review of Nutrition and Dietetics 56, 1-42.

Mead, P.S., Slutsker, L., Dietz, V., McCaig, L.F., Bresee, J.S., Shapiro, C., Griffin, P.M., Tauxe, R.V., 1999. Food-related illness and death in the United States. Emerging Infectious Diseases 5, 607-625.

Merrill, A.L., Watt, B.K., 1973. Energy value of foods: basis and derivation. Human Nutrition Research Branch, Agricultural Research Service, United States Department of Agriculture, Agricultural Handbook No. 74.

Miliotis, M.D., Bier, J.W. (Eds.), 2003. International Handbook of Foodborne Pathogens. Marcel Dekker, New York, NY.

Miller, D.S., 1980. Man's demand for energy. In: Blaxter, K. (Ed.), Food Chains and Human Nutrition. Applied Science Publishers, London, pp. 23-49.

Miller, M.F., Carr, M.A., Ramsey, C.B., Crockett, K.L., Hoover, L.C., 2001. Consumer thresholds for establishing the value of beef tenderness. Journal of Animal Science 79, 3062-3068.

Miller, M.F., Huffman, K.L., Gilbert, S.Y., Hamman, L.L., Ramsey, C.B., 1995. Retail consumer acceptance of beef tenderized with calcium chloride. Journal of Animal Science 73, 2308-2314.

Monnier, J.L., Hallegouet, B., Hinguant, S., Laurent, M., Auguste, P., Bahain, J.J., Falgueres, C., Gebhardt, A., Marguerie, D., Molines, N., Morzadec, H., Yokoyama, Y., 1994. A new regional group of the Lower Paleolithic in Brittany (France), recently dated by electron spin resonance. Comptes Rendus de l'Academie des Sciences, Serie II $319,155-160$. 
Mora, R., de la Torre, I., 2005. Percussion tools in Olduvai Beds I and II (Tanzania): implications for early human activities. Journal of Anthropological Archaeology 24, 179-192.

Mottram, D.S., 2007. The Maillard reaction: source of flavour in thermally processed foods. In: Berger, R.G. (Ed.), Flavours and Fragrances: Chemistry, Bioprocessing and Sustainability. Springer-Verlag, Berlin, pp. 269-283.

Moughan, P.J., Gall, M.P.J., Rutherfurd, S.M., 1996. Absorption of lysine and deoxyketosyllysine in an early-Maillard browned casein by the growing pig. Journal of Agricultural and Food Chemistry 44, 1520-1525.

Muir, J.G., Birkett, A., Brown, I., Jones, G., O'Dea, K., 1995. Food processing and maize variety affects amounts of starch escaping digestion in the small intestine. American Journal of Clinical Nutrition 61, 82-89.

Muir, J.G., O'Dea, K., 1992. Measurement of resistant starch: factors affecting the amount of starch escaping digestion in vitro. American Journal of Clinical Nutrition 56, $123-127$.

Murtaugh, M.A., Ma, K.N., Sweeney, C., Caan, B.J., Slattery, M.L., 2004. Meat consumption patterns and preparation, genetic variants of metabolic enzymes, and their association with rectal cancer in men and women. Journal of Nutrition 134, 776-784.

Noli, D., Avery, G., 1988. Protein poisoning and coastal subsistence. Journal of Archaeological Science 15, 395-401.

O'Connell, J.F., Hawkes, K., Lupo, K.D., Blurton-Jones, N.G., 2002. Male strategies and Plio-Pleistocene archaeology. Journal of Human Evolution 43, 831-872. 
Oka, K., Sakuarae, A., Fujise, T., Yoshimatsu, H., Sakata, T., Nakata, M., 2003. Food texture differences affect energy metabolism in rats. Journal of Dental Research 82, 491-494.

Ooi, S.T., Lorber, B., 2005. Gastroenteritis due to Listeria monocytogenes. Clinical Infectious Diseases 40, 1327-1332.

Oste, R., Sjodin, P., 1984. Effect of Maillard reaction products on protein digestion: in vivo studies on rats. Journal of Nutrition 114, 2228-2234.

Oste, R.E., Dahlqvist, A., Sjostrom, H., Noren, O., Miller, R., 1986. Effect of Maillard reaction products on protein digestion: in vitro studies. Journal of Agricultural and Food Chemistry 34, 355-358.

Oste, R.E., Miller, R., Sjostrom, H., Noren, O., 1987. Effect of Maillard reaction products on protein digestion: studies on pure compounds. Journal of Agricultural and Food Chemistry 35, 938-942.

Pálsson, G., 2001. Writing on Ice: the Ethnographic Notebooks of Vihljalmur Stefansson. University Press of New England, Hanover, NH.

Preece, R.C., Gowlett, J.A.J., Parfitt, S.A., Bridgland, D.R., Lewis, S.G., 2006. Humans in the Hoxnian: habitat, context and fire use at Beeches Pit, West Stow, Suffolk, UK. Journal of Quarternary Science 21, 485-496.

Purslow, P.P., 1999. The intramuscular connective tissue matrix and cell/matrix interactions in relation to meat toughness. 46th International Congress of Meat Science and Technology, Yokohama, Japan, 210-219.

Purslow, P.P., 2005. Intramuscular connective tissue and its role in meat quality. Meat Science 70, 435-477. 
Rerat, A., Calmes, R., Vaissade, P., Finot, P.A., 2002. Nutritional and metabolic consequences of the early Maillard reaction of heat treated milk in the pig: significance for man. European Journal of Nutrition 41, 1-11.

Rosell, M., Appleby, P., Key, T., 2005. Height, age at menarche, body weight and body mass index in life-long vegetarians. Public Health Nutrition 8, 870-875.

Rudloff, S., Lonnerdal, B., 1992. Solubility and digestibility of milk proteins in infant formulas exposed to different heat treatments. Journal of Pediatric Gastroenterology and Nutrition 15, 25-33.

Ruff, C.B., Trinkaus, E., Holliday, T.W., 1997. Body mass and encephalization in Pleistocene Homo. Nature 387, 173-176.

Rutherfurd, S.M., Moughan, P.J., 1998. The digestible amino acid composition of several milk proteins: application of a new bioassay. Journal of Dairy Science 81, 909-917.

Schick, K.D., Toth, N., 1994. Early stone age technology in Africa: a review and case study into the nature of spheroids and subspheroids. In: Coruccini, R.S., Ciochon, R.L. (Eds.), Integrative Paths to the Past: Paleoanthropological Advances in Honor of F. Clark Howell. Prentice-Hall, Englewood Cliffs, NJ, pp. 429-449.

Secor, S.M., 2003. Gastric function and its contribution to the postprandial metabolic response of the Burmese python Python molurus. Journal of Experimental Biology 206, 1621-1630.

Secor, S.M., in press. Specific dynamic action: a review of the postprandial metabolic response. Journal of Comparative Physiology, Part B. 
Secor, S.M., Boehm, M., 2006. Specific dynamic action of ambyostomatid salamanders and the effects of meal size, meal type, and body temperature. Physiological and Biochemical Zoology 79, 720-735.

Secor, S.M., Diamond, J., 1995. Adaptive responses to feeding in Burmese pythons: pay before pumping. Journal of Experimental Biology 198, 1313-1325.

Secor, S.M., Diamond, J., 1997. Determinants of the postfeeding metabolic response of Burmese pythons, Python molurus. Physiological Zoology 70, 202-212.

Secor, S.M., Faulkner, A.C., 2002. Effects of meal size, meal type, body temperature, and body size on the specific dynamic action of the marine toad, Bufo marinus.

Physiological and Biochemical Zoology 75, 557-571.

Seiquer, I., Diaz-Alguacil, J., Delgado-Andrade, C., Lopez-Frias, M., Hoyos, A.M., Galdo, G., Navarro, M.P., 2006. Diets rich in Maillard reaction products affect protein digestibility in adolescent males aged 11-14 y. American Journal of Clinical Nutrition $83,1082-1088$.

Sergant, J., Crombé, P., Perdaen, Y., 2006. The 'invisible' hearths: a contribution to the discernment of Mesolithic non-structured surface hearths. Journal of Archaeological Science 33, 999-1007.

Shipman, P., Walker, A., 1989. The costs of becoming a predator. Journal of Human Evolution 18, 373-392.

Shorrock, C., Ford, J.E., 1978. Metabolism of heat-damaged proteins in the rat: inhibition of amino acid uptake by 'unavailable peptides' isolated from enzymic digests of heatdamaged cod fillet. British Journal of Nutrition 40, 185-191. 
Silvester, K.R., Englyst, H.N., Cummings, J.H., 1995. Ileal recovery of starch from whole diets containing resistant starch measured in vitro and fermentation of ileal effluent. American Journal of Clinical Nutrition 62, 403-411.

Sinha, R., Peters, U., Cross, A.J., Kulldorff, M., Weissfeld, J.L., Pinsky, P.F., Rothman, N., Hayes, R.B., 2005. Meat, meat cooking methods and preservation, and risk for colorectal adenoma. Cancer Research 65, 8034-8041.

Speth, J.A., Spielmann, K.A., 1983. Energy source, protein metabolism, and huntergatherer subsistence strategies. Journal of Anthropological Archaeology 2, 1-31.

Speth, J.D., 1989. Early hominid hunting and scavenging: the role of meat as an energy source. Journal of Human Evolution 18, 329-343.

Spoor, F., Leakey, M.G., Gathogo, P.N., Brown, F.H., Antón, S.C., McDougall, I., Kiarie, C., Manthi, F.K., Leakey, L.N., 2007. Implications of new early Homo fossils from Ileret, east of Lake Turkana, Kenya. Nature 448, 688-691.

Stefansson, V., 1960. The Fat of the Land. Macmillan, New York.

Stettler, N., Schutz, Y., Whitehead, R., Jequier, E., 1992. Effect of malaria and fever on energy-metabolism in Gambian children. Pediatric Research 31, 102-106.

Stubbs, R.J., Whybrow, S., 2004. Energy density, diet composition and palatability: influences on overall food energy intake in humans. Physiology \& Behavior 81, $755-764$.

Sun, T., Laerke, H.N., Jorgenson, H., Knudsen, K.E.B., 2006. The effect of extrusion cooking of different starch sources on the in vitro and in vivo digestibility in growing pigs. Animal Feed Science and Technology 131, 66-85. 
Svihus, B., Uhlen, A.K., Harstad, O.M., 2005. Effect of starch granule structure, associated components and processing on nutritive value of cereal starch: a review. Animal Feed Science and Technology 122, 303-320.

Tanaka, J., 1980. The San Hunter-Gatherers of the Kalahari: a Study in Ecological Anthropology. University of Tokyo Press, Tokyo.

Tester, R.F., Qi, X., Karkalas, J., 2006. Hydrolysis of native starches with amylases. Animal Feed Science and Technology 130, 39-54.

Tester, R.F., Sommerville, M.D., 2000. Swelling and enzymatic hydrolysis of starch in low water systems. Journal of Cereal Science 33, 193-203.

Thieme, H., 2000. Lower Palaeolithic hunting weapons from Schöningen, Germany: the oldest spears in the world. Acta Anthropologica Sinica 19 (Supplement), 140-147.

Thieme, H., 2005. The Lower Paleolithic art of hunting. In: Gamble, C.S., Parr, M. (Eds.), The Hominid Individual in Context: Archaeological Investigations of Lower and Middle Paleolithic Landscapes, Locales and Artefacts. Routledge, London, pp. $115-132$.

Tornberg, E., 2005. Effects of heat on meat proteins: implications on structure and quality of meat products. Meat Science 70, 493-508.

Toth, N., Schick, K. (Eds.), 2006. The Oldowan: Case Studies into the Earliest Stone Age. Stone Age Institute Press, Gosport, IN.

Ungar, P.S., Grine, F.E., Teaford, M.F., 2006. Diet in early Homo: a review of the evidence and a new model of dietary versatility. Annual Review of Anthropology 35, 209-228. 
USDA, 1999. Livestock and poultry: world markets and trade. U.S. Department of Agriculture, Foreign Agriculture Service Circular Series FL\&P 2-99. http:// www.fas.usda.gov/dlp2/circular/1999/99-10LP/toc.htm.

USDA, 2008. USDA National Nutrient Database for Standard Reference (Release 21). U.S. Department of Agriculture, Agricultural Research Service, USDA Nutrient Data Laboratory. http://www.ars.usda.gov/ba/bhnrc/ndl.

Waldron, K.W., Parker, M.L., Smith, A.C., 2003. Plant cells walls and food quality. Comprehensive Reviews in Food Science and Food Safety 2, 101-119.

Wandsnider, L., 1997. The roasted and the boiled: food composition and heat treatment with special emphasis on pit-hearth cooking. Journal of Anthropological Archaeology $16,1-48$.

Wang, X., Parsons, C.M., 1998. Effect of raw material source, processing systems, and processing temperatures on amino acid digestibility of meat and bone meals. Poultry Science 77, 834-841.

Warriss, P.D., 2000. Meat Science: An Introductory Text. CABI Publishing, New York. Washburn, S.L., Lancaster, C.S., 1968. The evolution of hunting. In: Lee, R.B., DeVore, I. (Eds.), Man the Hunter. Harvard University Press, Cambridge, MA, pp. 293-303.

Westerterp, K.R., Wilson, S.A.J., Rolland, V., 1999. Diet induced thermogenesis measured over $24 \mathrm{~h}$ in a respiration chamber: effect of diet composition. International Journal of Obesity 23, 287-292.

WHO, 2008. Campylobacter. World Health Organization. http://www.who.int/topics/ campylobacter/en/. 
Wilson, R.A., 1975. Review of thermally produced imitation meat flavors. Journal of Agricultural and Food Chemistry 23, 1032-1037.

Wiseman, J., 2006. Variations in starch digestibility in non-ruminants. Animal Feed Science and Technology 130, 66-77.

Wobber, V., Hare, B., Wrangham, R., 2008. Great apes prefer cooked food. Journal of Human Evolution 55, 340-348.

Wood, B., Aiello, L.C., 1998. Taxonomic and functional implications of mandibular scaling in early hominins. American Journal of Physical Anthropology 105, 523-538.

Wrangham, R., 2009. Catching Fire: How Cooking Made Us Human. Basic Books, New York, NY.

Wrangham, R.W., 2006. The cooking enigma. In: Ungar, P. (Ed.), Early Hominin Diets: the Known, the Unknown, and the Unknowable. Oxford University Press, New York, NY, pp. 308-323.

Wrangham, R.W., Conklin-Brittain, N.L., 2003. Cooking as a biological trait. Comparative Biochemistry and Physiology, Part A 136, 35-46.

Wrangham, R.W., Jones, J.H., Laden, G., Pilbeam, D., Conklin-Brittain, N.L., 1999. The raw and the stolen: cooking and the ecology of human origins. Current Anthropology 40, 567-594.

Xu, W.H., Dai, Q., Xiang, Y.B., Zhao, G.M., Zheng, W., Gao, Y.T., Ruan, Z.X., Cheng, J.R., Shu, X.O., 2006. Animal food intake and cooking methods in relation to endometrial cancer risk in Shanghai. British Journal of Cancer 95, 1586-1592.

Yamakoshi, G., Sugiyama, Y., 1995. Pestle-pounding behavior of wild chimpanzees at Bossou, Guinea: a newly observed tool-using behavior. Primates 36, 489-500. 
Yeomans, M.R., 1998. Taste, palatability and the control of appetite. Proceedings of the Nutrition Society 57, 609-615.

Yeomans, M.R., Gray, R.W., Mitchell, C.J., True, S., 1997. Independent effects of palatability and within-meal pauses on intake and appetite ratings in human volunteers. Appetite 29,61-76. 
Table 1. Proposed consequences of cooking.

\begin{tabular}{|c|c|c|c|}
\hline Consequence & Mechanism & $\begin{array}{l}\text { Effect on } \\
\text { energy gain }\end{array}$ & Source \\
\hline Higher digestibility & Starch gelatinization & Increase & Svihus et al., 2005 \\
\hline Higher digestibility & Amylose & Increase & Brown et al., 2003 \\
\hline Higher digestibility & Deactivate trypsin inhibitors & Increase & $\begin{array}{l}\text { Borenstein and } \\
\text { Lachance, } 1988\end{array}$ \\
\hline Higher digestibility & Protein denaturation & Increase & $\begin{array}{l}\text { Davies et al., 1987; } \\
\text { Gaman and } \\
\text { Sherrington, } 1996\end{array}$ \\
\hline Same digestibility & Protein denaturation & & $\begin{array}{l}\text { Bodwell and } \\
\text { Anderson, 1986; } \\
\text { Borenstein and } \\
\text { Lachance, } 1988\end{array}$ \\
\hline Lower digestibility & Protein covalent bonds & Decrease & $\begin{array}{l}\text { Borenstein and } \\
\text { Lachance, } 1988\end{array}$ \\
\hline Lower digestibility & $\begin{array}{l}\text { Maillard reaction, causing } \\
\text { reduced digestion of amides and } \\
\text { sugars linked to each other }\end{array}$ & Decrease & Jenkins, 1988 \\
\hline Lower digestibility & $\begin{array}{l}\text { Amino acids converted to other } \\
\text { compounds }\end{array}$ & Decrease & $\begin{array}{l}\text { Borenstein and } \\
\text { Lachance, } 1988\end{array}$ \\
\hline Safety & Reduced toxins & Increase? & $\begin{array}{l}\text { Barham, 2001; } \\
\text { Friedman, } 2003\end{array}$ \\
\hline Increased edibility & $\begin{array}{l}\text { Increased safety, improved } \\
\text { taste, etc. }\end{array}$ & Increase? & Friedman, 2003 \\
\hline Easier access & Defrosting & - & Brace, 1995 \\
\hline $\begin{array}{l}\text { Improved texture / } \\
\text { tenderness }\end{array}$ & Softening meat & Increase & Boback et al., 2007 \\
\hline
\end{tabular}




\begin{tabular}{|l|l|l|l|}
\hline Compromised & Toughening meat through & Barham, 2001; \\
texture / tenderness & improper cooking methods & McGee, 2004 \\
\hline Compromised & Protein contraction causes water- & Barham, 2001; \\
texture / tenderness & loss in meat & McGee, 2004 \\
\hline Improved flavor & Formation of new compounds & - & Charley, 1982; \\
& (e.g. lactones, sulfides, & Barham, 2001 \\
\hline Improved appearance & Color changes in meat & \\
\hline Improved aroma & Aromatic compounds formed in & - & Tornberg, 2005 \\
\hline Improved storage & Baillard reaction & Charley, 1982 \\
\hline Increase water- & Change protein structure of & - & \\
\hline holding & meat & Friedman, 2003 \\
\hline Reduce water-holding & Evaporation & Tornberg, 2005 \\
\hline Dripping loss & Reduction in fat content & Decrease & Bender, 1992; \\
\hline & & & USDA, 2008 \\
\hline
\end{tabular}

Numerous nutritional consequences of cooking have been found or suggested. Rather than providing an exhaustive list, this table is intended to illustrate some of the major concepts. Note that particularly with respect to meat and/or protein, suggested consequences include opposing effects. 
Table 2. Body Mass Index by diet type.

\begin{tabular}{|c|c|c|c|c|c|c|}
\hline$\%$ raw food & Sex & Diet type & $\begin{array}{l}\text { Mean or } \\
\text { median } \\
\text { age }(y)\end{array}$ & $\mathrm{N}$ & BMI & Reference \\
\hline Cooked & $F$ & $\begin{array}{l}\text { "Typical American } \\
\text { diet" }\end{array}$ & 53 & 7 & 25.4 & Fontana et al., 2005 \\
\hline $\begin{array}{l}\text { Mostly } \\
\text { cooked }\end{array}$ & $\mathrm{F}$ & $\begin{array}{l}\text { Mixed diet (not } \\
\text { vegetarian) }\end{array}$ & 45 & 23147 & 24.2 & Rosell et al., 2005 \\
\hline $\begin{array}{l}\text { Mostly } \\
\text { cooked }\end{array}$ & $\mathrm{F}$ & $\begin{array}{l}\text { Vegetarian since } \\
\text { birth }\end{array}$ & 43 & 257 & 23.7 & Rosell et al., 2005 \\
\hline $\begin{array}{l}\text { Mostly } \\
\text { cooked }\end{array}$ & $\mathrm{F}$ & $\begin{array}{l}\text { Vegetarian starting } \\
\text { between } 1 \text { and } 9 \\
\text { years old }\end{array}$ & 33 & 257 & 23.9 & Rosell et al., 2005 \\
\hline $\begin{array}{l}\text { Mostly } \\
\text { cooked }\end{array}$ & $F$ & $\begin{array}{l}\text { Vegetarian starting } \\
\text { between } 10 \text { and } 14 \\
\text { years old }\end{array}$ & 25 & 1042 & 23.8 & Rosell et al., 2005 \\
\hline $\begin{array}{l}\text { Mostly } \\
\text { cooked }\end{array}$ & $F$ & $\begin{array}{l}\text { Vegetarian starting } \\
\text { between } 15 \text { and } 19 \\
\text { years old }\end{array}$ & 27 & 2226 & 23.6 & Rosell et al., 2005 \\
\hline $\begin{array}{l}\text { Mostly } \\
\text { cooked }\end{array}$ & $\mathrm{F}$ & $\begin{array}{l}\text { Vegetarian starting } \\
\text { after } 19 \text { years old }\end{array}$ & 39 & 7880 & 23.5 & Rosell et al., 2005 \\
\hline Mostly raw & $\mathrm{F}$ & $\begin{array}{l}\text { Vegan; includes } \\
\text { cooked vegetables }\end{array}$ & 53 & 87 & 21.5 & Donaldson, 2001 \\
\hline All raw & $\mathrm{F}$ & $\begin{array}{l}\text { Vegetarian and raw } \\
\text { for mean of } 3.6 \\
\text { years }\end{array}$ & 56 & 7 & 20.1 & Fontana et al., 2005 \\
\hline All raw & $\mathrm{F}$ & Vegetarian & & & 20 & Hobbs, 2005 \\
\hline
\end{tabular}




\begin{tabular}{|c|c|c|c|c|c|c|}
\hline Cooked & $M$ & $\begin{array}{l}\text { "Typical American } \\
\text { diet" }\end{array}$ & 52 & 11 & 25.5 & Fontana et al., 2005 \\
\hline $\begin{array}{l}\text { Mostly } \\
\text { cooked }\end{array}$ & M & $\begin{array}{l}\text { Mixed diet (not } \\
\text { vegetarian) }\end{array}$ & 48 & 6103 & 25.2 & Rosell et al., 2005 \\
\hline $\begin{array}{l}\text { Mostly } \\
\text { cooked }\end{array}$ & $\mathrm{M}$ & $\begin{array}{l}\text { Vegetarian since } \\
\text { birth }\end{array}$ & 47 & 122 & 24.2 & Rosell et al., 2005 \\
\hline $\begin{array}{l}\text { Mostly } \\
\text { cooked }\end{array}$ & M & $\begin{array}{l}\text { Vegetarian starting } \\
\text { between } 1 \text { and } 9 \\
\text { years old }\end{array}$ & 42 & 71 & 25.4 & Rosell et al., 2005 \\
\hline $\begin{array}{l}\text { Mostly } \\
\text { cooked }\end{array}$ & M & $\begin{array}{l}\text { Vegetarian starting } \\
\text { between } 10 \text { and } 14 \\
\text { years old }\end{array}$ & 30 & 118 & 24.4 & Rosell et al., 2005 \\
\hline $\begin{array}{l}\text { Mostly } \\
\text { cooked }\end{array}$ & $M$ & $\begin{array}{l}\text { Vegetarian starting } \\
\text { between } 15 \text { and } 19 \\
\text { years old }\end{array}$ & 30 & 538 & 24.2 & Rosell et al., 2005 \\
\hline $\begin{array}{l}\text { Mostly } \\
\text { cooked }\end{array}$ & M & $\begin{array}{l}\text { Vegetarian starting } \\
\text { after } 19 \text { years old }\end{array}$ & 41 & 3011 & 24.3 & Rosell et al., 2005 \\
\hline Mostly raw & M & $\begin{array}{l}\text { Vegan; includes } \\
\text { cooked vegetables }\end{array}$ & 57 & 54 & 22.9 & Donaldson, 2001 \\
\hline All raw & $M$ & $\begin{array}{l}\text { Vegetarian and raw } \\
\text { for mean of } 3.6 \\
\text { years }\end{array}$ & 53 & 11 & 20.7 & Fontana et al., 2005 \\
\hline All raw & $M$ & Vegetarian & & & 21.0 & Hobbs, 2005 \\
\hline $70-79 \%$ raw & $\mathrm{F}+\mathrm{M}$ & $\begin{array}{l}\text { Overall sample: } \\
44.2 \% \text { meat-eaters, } \\
32.2 \% \text { vegetarian, } \\
23.6 \% \text { vegan }\end{array}$ & Adult & 66 & 21.1 & $\begin{array}{l}\text { Koebnick et al., } \\
1999\end{array}$ \\
\hline
\end{tabular}




\begin{tabular}{|c|c|c|c|c|c|c|}
\hline $80-89 \%$ raw & $\mathrm{F}+\mathrm{M}$ & “6 & Adult & 103 & 21.0 & $\begin{array}{l}\text { Koebnick et al., } \\
1999\end{array}$ \\
\hline $90-99 \%$ raw & $\mathrm{F}+\mathrm{M}$ & “" & Adult & 248 & 20.2 & $\begin{array}{l}\text { Koebnick et al., } \\
1999\end{array}$ \\
\hline $100 \%$ raw & $\mathrm{F}+\mathrm{M}$ & “" & Adult & 96 & 19.3 & $\begin{array}{l}\text { Koebnick et al., } \\
1999\end{array}$ \\
\hline
\end{tabular}

In studies by Rosell et al. (2005), ages are medians. BMI for studies by Koebnick et al. (1999) were read off a graph. For all raw-foodists in the Koebnick et al. (1999) study, the mean percentage of raw food eaten was $91 \%$ (obtained by self-report), age-adjusted BMI was 20.1 (female), 20.7 (male). 
Table 3. Ileal digestibility of starch (\%) in relation to processing.

\begin{tabular}{|c|c|c|c|c|c|c|c|}
\hline & & & ivivo & & vitro & & \\
\hline $\begin{array}{l}\text { Starch } \\
\text { type }\end{array}$ & $\begin{array}{l}\text { Starch } \\
\text { source }\end{array}$ & Raw & Cooked & Raw & Cooked & $\begin{array}{l}\text { Change in } \\
\text { digestibility from } \\
\text { raw to cooked }\end{array}$ & Reference \\
\hline$A$ & Wheat & 71.2 & 96.0 & & & $+34 \%$ & Muir et al., 1995 \\
\hline A & Oats & & & 74.5 & 95.7 & $+28 \%$ & $\begin{array}{l}\text { Muir and O'Dea, } \\
1992\end{array}$ \\
\hline A & Barley & 93 & 99 & & & $+6 \%$ & $\begin{array}{l}\text { Sun et al., } 2006 \\
\text { (pigs) }\end{array}$ \\
\hline $\mathrm{B}$ & $\begin{array}{l}\text { Green } \\
\text { banana }\end{array}$ & 47.3 & 98.8 & 45.8 & & $+109 \%$ & $\begin{array}{l}\text { Langkilde et al., } \\
2002\end{array}$ \\
\hline $\mathrm{B}$ & $\begin{array}{l}\text { Green } \\
\text { banana }\end{array}$ & 49.4 & 96.9 & & & $+96 \%$ & Muir et al., 1995 \\
\hline B & Plantain & & & 53.6 & 100 & $+87 \%$ & $\begin{array}{l}\text { Englyst and } \\
\text { Cummings, } 1986 \\
\end{array}$ \\
\hline $\bar{B}$ & Potato & & 96.7 & 50.7 & & $(+91 \%)$ & $\begin{array}{l}\text { Englyst and } \\
\text { Cummings, } 1987\end{array}$ \\
\hline $\mathrm{B}$ & Potato & $32-47$ & 98 & & & $+108-206 \%$ & $\begin{array}{l}\text { Sun et al., } 2006 \\
\text { (pigs) }\end{array}$ \\
\hline $\bar{C}$ & Pea & 80 & 91 & & & $+14 \%$ & $\begin{array}{l}\text { Sun et al., } 2006 \\
\text { (pigs) }\end{array}$ \\
\hline
\end{tabular}

Data are for humans unless otherwise stated. Studies in vivo used collections of ileal fluids in ileostomy patients or cannulated pigs. Studies in vitro measure resistant starch (RS) as starch that is not hydrolyzed following six hours of enzymatic hydrolysis. Silvester et al. (1995) showed that $97 \%$ of resistant starch assayed in foods was recovered in ileal fluids. 
Table 4. Calories per gram of dry matter for selected meats, raw and cooked (roasted).

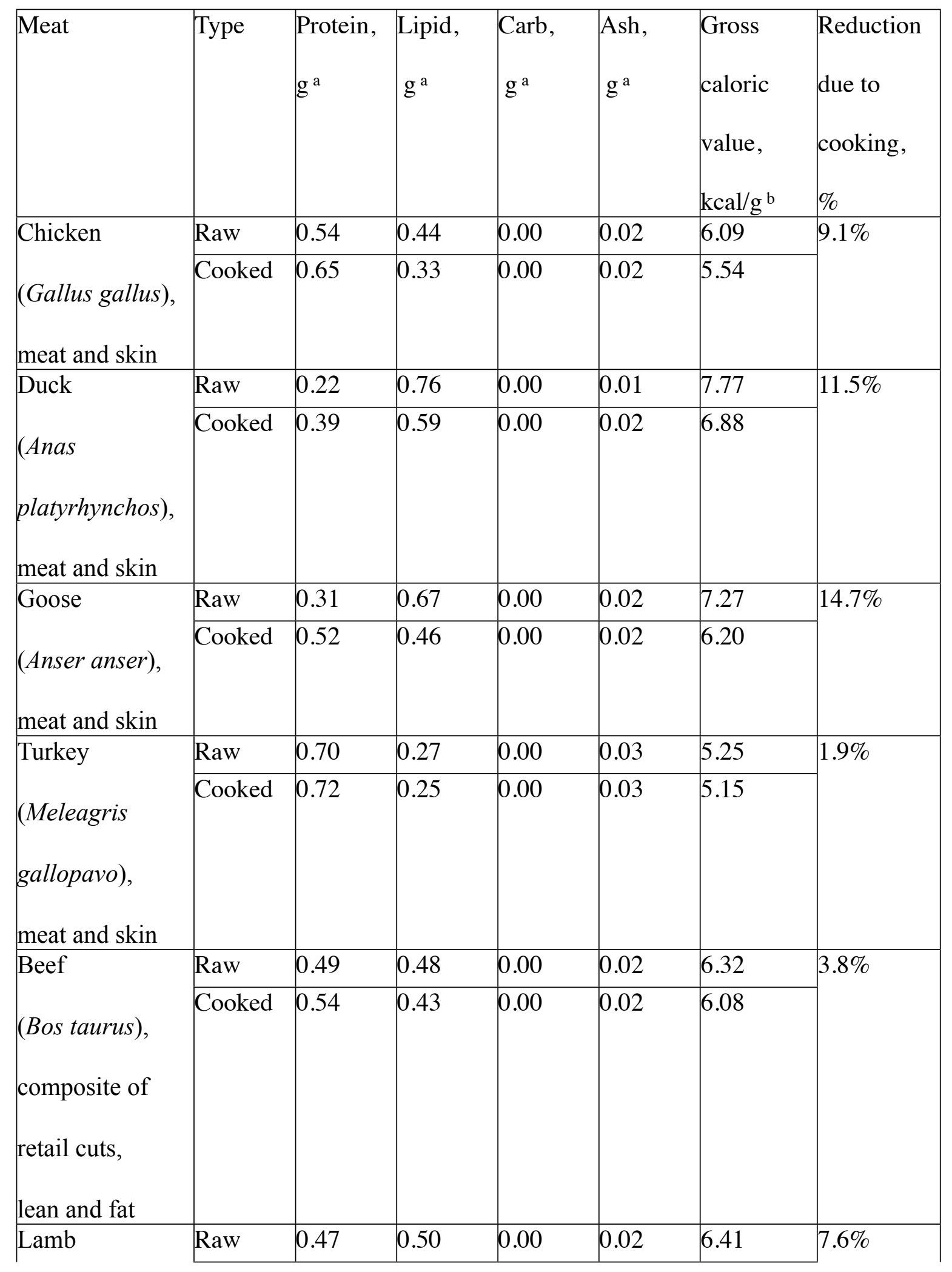




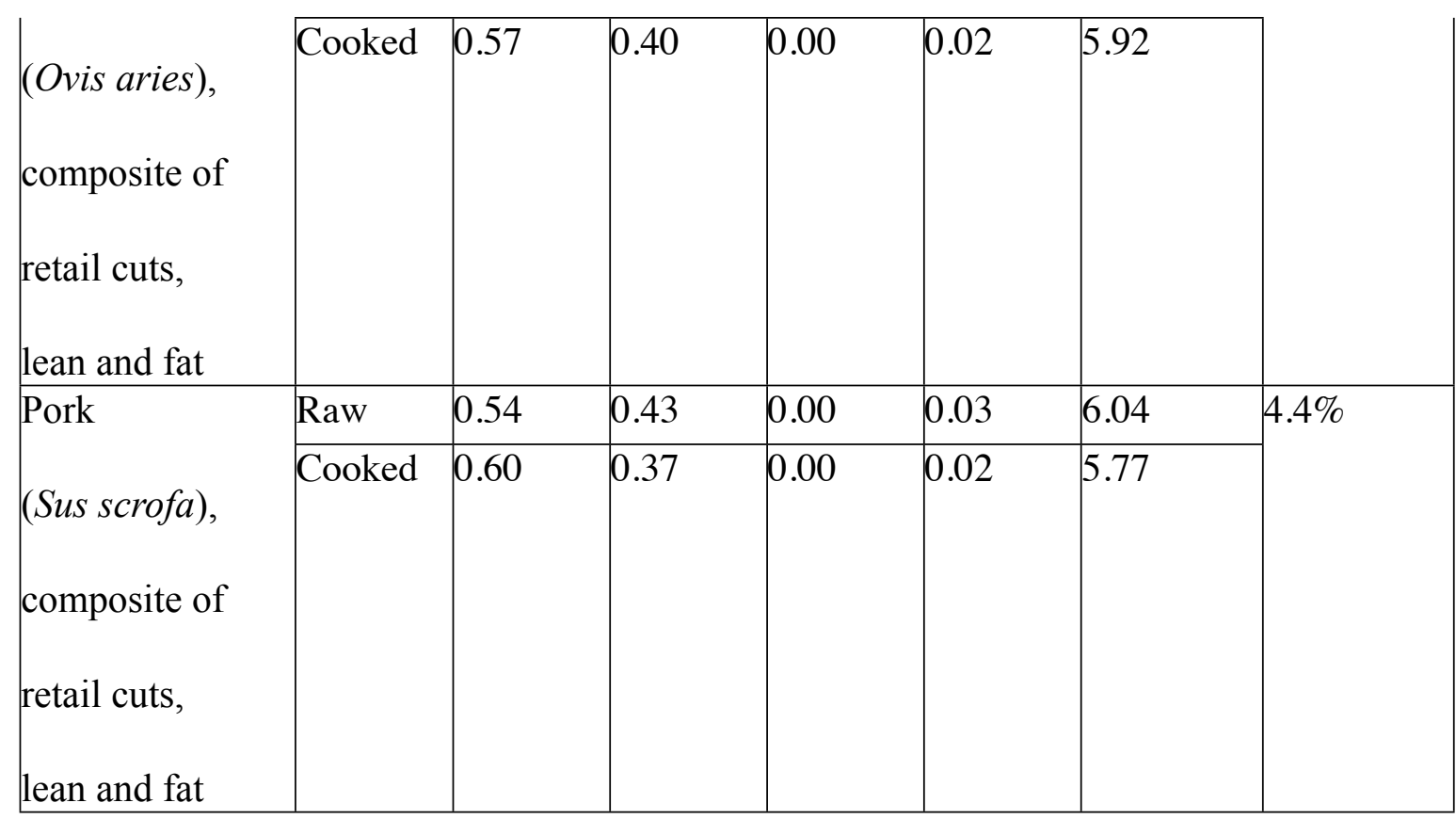

(a) Source: USDA (2008)

(b) Calculated by multiplying protein, lipid, carbohydrate and ash contents by 4, 9, 4 and 0 $\mathrm{kcal} / \mathrm{g}$, respectively (Merrill and Watt, 1973) 
Table 5. Annual energetic cost of foodborne illness from meat given customary cooking.

\begin{tabular}{|l|l|l|l|l|}
\hline Bacteria & Annual number & Mean body & Mean duration & Annual energetic cost of \\
& of illnesses & temperature & of fever (days) & foodborne illness \\
& & elevation $\left({ }^{\circ} \mathrm{C}\right)$ & {$[\mathrm{C}]$} & $($ multiple of daily BMR) \\
& {$[\mathrm{B}]$} & & {$[\mathrm{D}]=\mathrm{A} \times \mathrm{B} \times \mathrm{C} \times 0.13$} \\
\hline E. coli $\mathrm{O} 157$ & 0.00023 & $1^{\mathrm{a}}$ & $8^{\mathrm{c}}$ & 0.00024 \\
\hline Salmonella & 0.00502 & $2^{\mathrm{b}}$ & $2^{\mathrm{d}}$ & 0.00261 \\
\hline Campylobacter & 0.00733 & $2^{\mathrm{b}}$ & $4^{\mathrm{e}}$ & 0.00763 \\
\hline Listeria & 0.00001 & $2^{\mathrm{b}}$ & $3^{\mathrm{f}}$ & 0.00000 \\
\hline Total & 0.01259 & $\mathrm{n} / \mathrm{a}$ & $\mathrm{n} / \mathrm{a}$ & 0.01048 \\
\hline
\end{tabular}

(a) E. coli associated with low-grade fever

(b) Salmonella, Campylobacter and Listeria associated with moderate-grade fever

(c) Average of 8 days (FDA, 2002); 5-10 days (Miliotis and Bier, 2003)

(d) Typically 1-2 days or may be prolonged (FDA, 2002)

(e) 3-6 days (WHO, 2008); 2-6 days (Miliotis and Bier, 2003)

(f) Typically 1-3 days, up to 1 week (Ooi and Lorber, 2005) 
Table 6. Annual foodborne illnesses from meat given customary consumption of raw meat.

\begin{tabular}{|c|c|c|c|c|c|c|}
\hline Meat & Bacteria & $\begin{array}{l}\text { Samples } \\
\text { infected } \\
(\%)[\mathrm{A}]\end{array}$ & $\begin{array}{l}\text { Annual per } \\
\text { capita } \\
\text { intake }(\mathrm{kg}) \\
{[\mathrm{B}]}\end{array}$ & $\begin{array}{l}\text { Annual } \\
\text { servings } \\
{[\mathrm{C}]=\mathrm{B} \div} \\
0.25\end{array}$ & $\begin{array}{l}\text { Assumed } \\
\text { infection } \\
\text { rate (\%) } \\
\text { [D] }\end{array}$ & $\begin{array}{l}\text { Annual number } \\
\text { of illnesses } \\
{[\mathrm{E}]=\mathrm{A} \times \mathrm{C} \times \mathrm{D}}\end{array}$ \\
\hline \multirow[t]{4}{*}{ Beef } & E. coli $\mathrm{O} 157$ & 18.4 & 44.6 & 178.4 & 10 & 3.3 \\
\hline & Salmonella & 24.8 & 44.6 & 178.4 & 10 & 4.4 \\
\hline & Campylobacter & 12.1 & 44.6 & 178.4 & 10 & 2.2 \\
\hline & Listeria & 24.8 & 44.6 & 178.4 & 10 & 4.4 \\
\hline \multirow[t]{4}{*}{ Pork } & E. coli $\mathrm{O} 157$ & 1.8 & 30.7 & 122.8 & 10 & 0.2 \\
\hline & Salmonella & 18.4 & 30.7 & 122.8 & 10 & 2.3 \\
\hline & Campylobacter & 9.0 & 30.7 & 122.8 & 10 & 1.1 \\
\hline & Listeria & 24.8 & 30.7 & 122.8 & 10 & 3.0 \\
\hline \multirow[t]{4}{*}{ Mutton } & E. coli $\mathrm{O} 157$ & 1.8 & 0.6 & 2.4 & 10 & 0.0 \\
\hline & Salmonella & 50.0 & 0.6 & 2.4 & 10 & 0.1 \\
\hline & Campylobacter & 24.8 & 0.6 & 2.4 & 10 & 0.1 \\
\hline & Listeria & 32.1 & 0.6 & 2.4 & 10 & 0.1 \\
\hline \multirow[t]{5}{*}{ Poultry } & E. coli $\mathrm{O} 157$ & 1.8 & 46.7 & 186.8 & 10 & 0.3 \\
\hline & Salmonella & 32.1 & 46.7 & 186.8 & 10 & 6.0 \\
\hline & Campylobacter & 49.0 & 46.7 & 186.8 & 10 & 9.2 \\
\hline & Listeria & 29.0 & 46.7 & 186.8 & 10 & 5.4 \\
\hline & & & & & Total & 42.1 \\
\hline
\end{tabular}

